\title{
THE CHEST LEAD ELECTROCARDIOGRAM IN HEALTH
}

\author{
BY \\ AUBREY LEATHAM \\ From the Cardiac Department of the London Hospital
}

Received August 19, 1949

The purpose of this paper is to describe the normal pattern and variation of the electrocardiogram in the chest leads in common use. Standards for the limb lead electrocardiogram in health have been determined by many investigators including Lewis and Gilder (1912), Jensen, Smith, and Cartwright (1932), Shipley and Hallaran (1936), Ashman and Hull (1937), Chamberlain and Hay (1939), Barnes (1940), Hoskin and Jonescu (1940), Pardee (1941), Hall, Stewart, and Manning (1942), Graybiel and others (1944), and Stewart and Manning (1944). In the same way, the normal appearance of certain chest lead electrocardiograms have been described by Kossman and Johnston (1935), Sorsky and Wood (1937), Wood and Selzer (1939), Deeds and Barnes (1940), Shanno (1940), Larsen and Skúlason (1941), Myers and others (1947), Grewin (1948), and Dolgin, Grau, and Katz (1949). Comparisons have been made by some of these authors and by others, including Groedel (1939), Wolferth and Wood (1940), Hecht (1942), Wallace and Grossman (1946), and Hull, Tucker and Weilbaecher (1948).

In this investigation 100 healthy adults were personally examined clinically, radiologically, and electrocardiographically. The leads in each subject included standard limb leads and unipolar limb leads (not analysed in this paper), and chest leads in positions 1 to 6 (American Heart Association, 1938) and in position 7 in the posterior axillary line (Evans and Hunter, 1943); the indifferent electrode was connected to the right arm (CR), left leg (CF), and through resistances to Wilson's central terminal (V), while the exploring chest electrode (Burger's suction type) remained in the same position. Standardization was normal $(1 \mathrm{mv} .=1 \mathrm{~cm}$. deflection) or half normal $(1 \mathrm{mv} .=$ $0.5 \mathrm{~cm}$.). The unipolar limb leads were taken by Wilson's method using resistances with standardization to one and a half times normal $(1 \mathrm{mv} .=1.5 \mathrm{~cm}$. deflection), or normal, or twice normal in some of the earlier records. The entire technique was carried out by the author to eliminate personal variation.

The CR and V leads were taken in all subjects, but the CF leads were discontinued after the first 50 (aged 40 to 71 years) because of their variability. The voltage at the chest electrode was usually much higher than at the indifferent electrode, whether CR, V, or even CF was used, so that the pattern of the chest lead electrocardiogram depended more on the position of the chest electrode than on the choice of the indifferent electrode (Wilson, 1937). When the findings were common to CR, $\mathrm{V}$, and $\mathrm{CF}$, the chest leads were referred to as $\mathrm{Cl}$ or $\mathrm{C} 2$ or $\mathrm{C3}$, etc.

Of the 100 healthy adults the majority were males; 50 were between the ages of 18 and 40 years (average 27), and 50 were between 40 and 71 years (average 53). They were without symptoms or abnormal physical signs and the blood pressure was always normal. Fluoroscopy of the heart and chest was normal. The records were always taken on a couch in the semi-recumbent position. The majority of the younger subjects were either medical students, medical officers, or hospital porters. Many of the older group had indigestion, but the pain of coronary artery disease was not simulated; if there was doubt they were excluded. It happened that the subjects were seldom stout, but six women with cyesis were deliberately included. 
All records were taken with the Elmqvist three-channel electrocardiograph which had a frequency response about linear to 400 cycles, and consisted of valve amplifiers with resistance capacity coupling and oil damped mirror galvanometers. The results for the $P, Q, R, S, S-T$ segment deviation, and $\mathrm{T}$ waves are summarized in simple distribution tables. Standard deviations and coefficients of variation are given in Table $X$ for the older group of 50 subjects. These calculations were not made for the younger group of 50 subjects, but no great difference would be expected since the distribution tables for the two groups are similar. These calculations were only made for the $\mathbf{R}$, $\mathrm{S}$, and $\mathrm{T}$ waves since the measurements of $\mathrm{P}, \mathrm{Q}$, and $\mathrm{S}-\mathrm{T}$ segment deviation were too small.

\section{The P WAVE}

The height of the $P$ wave (Table I) was measured to the nearest $0.5 \mathrm{~mm}$. and the iso-electric line between the $\mathrm{T}$ and $\mathrm{P}$ waves was used as the reference level. The height was nearly constant in all chest positions (Fig. 1) but slightly less in $\mathrm{Cl}$ and $\mathrm{C} 7$. The $\mathrm{P}$ wave was most pointed in $\mathrm{C} 1$. The

TABLE I

Height of P Wave in Healthy Subjects

\begin{tabular}{|c|c|c|c|c|c|c|c|c|c|c|c|c|c|c|c|c|c|c|c|c|c|}
\hline \multirow{2}{*}{$\begin{array}{l}\text { Height of } \\
P \text { in } \mathrm{mm} .\end{array}$} & \multicolumn{7}{|c|}{ CR (100 cases) } & \multicolumn{7}{|c|}{ V (100 cases) } & \multicolumn{7}{|c|}{ CF (50 cases) } \\
\hline & 1 & 2 & $\begin{array}{c}\text { Chest } \\
3\end{array}$ & posi & $\begin{array}{c}\text { itions } \\
5\end{array}$ & s 6 & 7 & 1 & 2 & $\begin{array}{c}\text { Chest } \\
3\end{array}$ & $p_{4}^{p o s i}$ & $\begin{array}{c}\text { ition } \\
5\end{array}$ & Is 6 & 7 & 1 & 2 & Ches & ${ }_{4}^{p o s}$ & $\begin{array}{c}\text { tions } \\
5\end{array}$ & 6 & 7 \\
\hline $\begin{array}{c}3.0 \\
2.5 \\
2.0 \\
1.5 \\
1.0 \\
0.5 \\
0 \\
-0.5 \\
-1.0 \\
-1.5 \\
-2.0\end{array}$ & $\begin{array}{r}- \\
5 \\
12 \\
73 \\
9 \\
1 \\
= \\
= \\
-\end{array}$ & $\begin{array}{r}1 \\
0 \\
5 \\
17 \\
73 \\
4 \\
- \\
= \\
= \\
-\end{array}$ & $\begin{array}{l}\overline{1} \\
10 \\
25 \\
61 \\
3 \\
= \\
= \\
=\end{array}$ & $\begin{array}{l}\overline{-} \\
10 \\
27 \\
62 \\
1 \\
= \\
= \\
= \\
-\end{array}$ & $\begin{array}{l}- \\
\overline{10} \\
23 \\
65 \\
2 \\
= \\
= \\
=\end{array}$ & $\begin{array}{l}- \\
10 \\
23 \\
66 \\
1 \\
= \\
= \\
=\end{array}$ & $\begin{array}{r}- \\
5 \\
18 \\
73 \\
4 \\
= \\
= \\
=\end{array}$ & $\begin{array}{r}- \\
1 \\
2 \\
20 \\
63 \\
1 \\
6 \\
7 \\
-\end{array}$ & $\begin{array}{r}- \\
1 \\
2 \\
26 \\
63 \\
4 \\
2 \\
2 \\
-\end{array}$ & $\begin{array}{l}\overline{-} \\
\overline{4} \\
30 \\
59 \\
7 \\
\overline{-} \\
=\end{array}$ & $\begin{array}{l}= \\
\overline{-} \\
29 \\
66 \\
4 \\
= \\
= \\
-\end{array}$ & $\begin{array}{l}- \\
- \\
1 \\
27 \\
67 \\
5 \\
= \\
=\end{array}$ & $\begin{array}{l}- \\
\bar{Z} \\
25 \\
66 \\
7 \\
= \\
= \\
-\end{array}$ & $\begin{array}{l}= \\
\bar{Z} \\
13 \\
73 \\
14 \\
= \\
=\end{array}$ & $\begin{array}{c}- \\
\overline{-} \\
\overline{-} \\
3 \\
4 \\
2 \\
5 \\
24 \\
5 \\
7\end{array}$ & $\begin{array}{r}- \\
1 \\
2 \\
10 \\
6 \\
9 \\
16 \\
4 \\
2\end{array}$ & $\begin{array}{r}- \\
\overline{1} \\
1 \\
3 \\
9 \\
12 \\
12 \\
10 \\
3 \\
-\end{array}$ & $\begin{array}{r}- \\
\overline{-} \\
\overline{2} \\
9 \\
25 \\
10 \\
4 \\
=\end{array}$ & $\begin{array}{r}- \\
= \\
-1 \\
8 \\
27 \\
10 \\
4 \\
-\end{array}$ & $\begin{array}{l}- \\
\overline{-} \\
\overline{1} \\
8 \\
22 \\
15 \\
4 \\
-\end{array}$ & $\begin{array}{l}= \\
\bar{Z} \\
\overline{ } \\
\overline{7} \\
8 \\
23 \\
12 \\
=\end{array}$ \\
\hline $\begin{array}{l}\text { Mean } \\
\text { height }\end{array}$ & $1 \cdot 0$ & $1 \cdot 1$ & $1 \cdot 2$ & $1 \cdot 2$ & 1.2 & $1 \cdot 2$ & $1 \cdot 1$ & 0.5 & 0.6 & 0.6 & 0.6 & 0.6 & 0.6 & 0.5 & -0 & & & & & & -0.4 \\
\hline
\end{tabular}

In Tables I to IX the figures indicate the number of subjects.

duration of the $\mathbf{P}$ wave was about the same in right and left chest leads as in lead II. Graybiel (1944) found that the duration in lead II varied from 0.02 to $0.15 \mathrm{sec}$. with the majority less than 0.1 sec. The duration of the $P$ wave in $V$ chest leads was often slightly shorter than in $C R$. The $P$ wave was bifid (Fig. 1) in 17 subjects, most commonly in right chest leads and the first peak was usually larger than the second. A bifid $P$ wave was more frequent in chest leads than in limb leads. It was absent from the limb leads if found only in $\mathrm{C} 1$ to $\mathrm{C} 3$ and it was more frequent in $\mathrm{CR}$ than in $\mathrm{V}$ or CF leads.

In CR leads $P$ was never negative, seldom over $2 \mathrm{~mm}$. high, but once $3 \mathrm{~mm}$. in CR2, never diphasic, and not flat, except once in CR1. In V1 and V2 the P wave was sometimes $1 \mathrm{~mm}$. negative, and it was diphasic in V1 in 18 subjects and in V2 in six. In V3 to V7 the P wave was iso-electric or positive, and rarely over $1 \mathrm{~mm}$. high. The $P$ wave in CF leads was often negative, especially in CF1 and CF2.

The P-R interval was measured from the onset of $P$ to the onset of QRS, and it was approximately the same length in lead II as in chest leads whether on the right or left. It was within the normal limits of 0.12 to $0.20 \mathrm{sec}$. (White, 1944), except once, when it measured $0.28 \mathrm{sec}$, and similar values have been found in health by Graybiel and others (1944), and Stewart and Manning (1944). Depression of the P-R segment was usually associated with S-T segment depression, and it is considered 


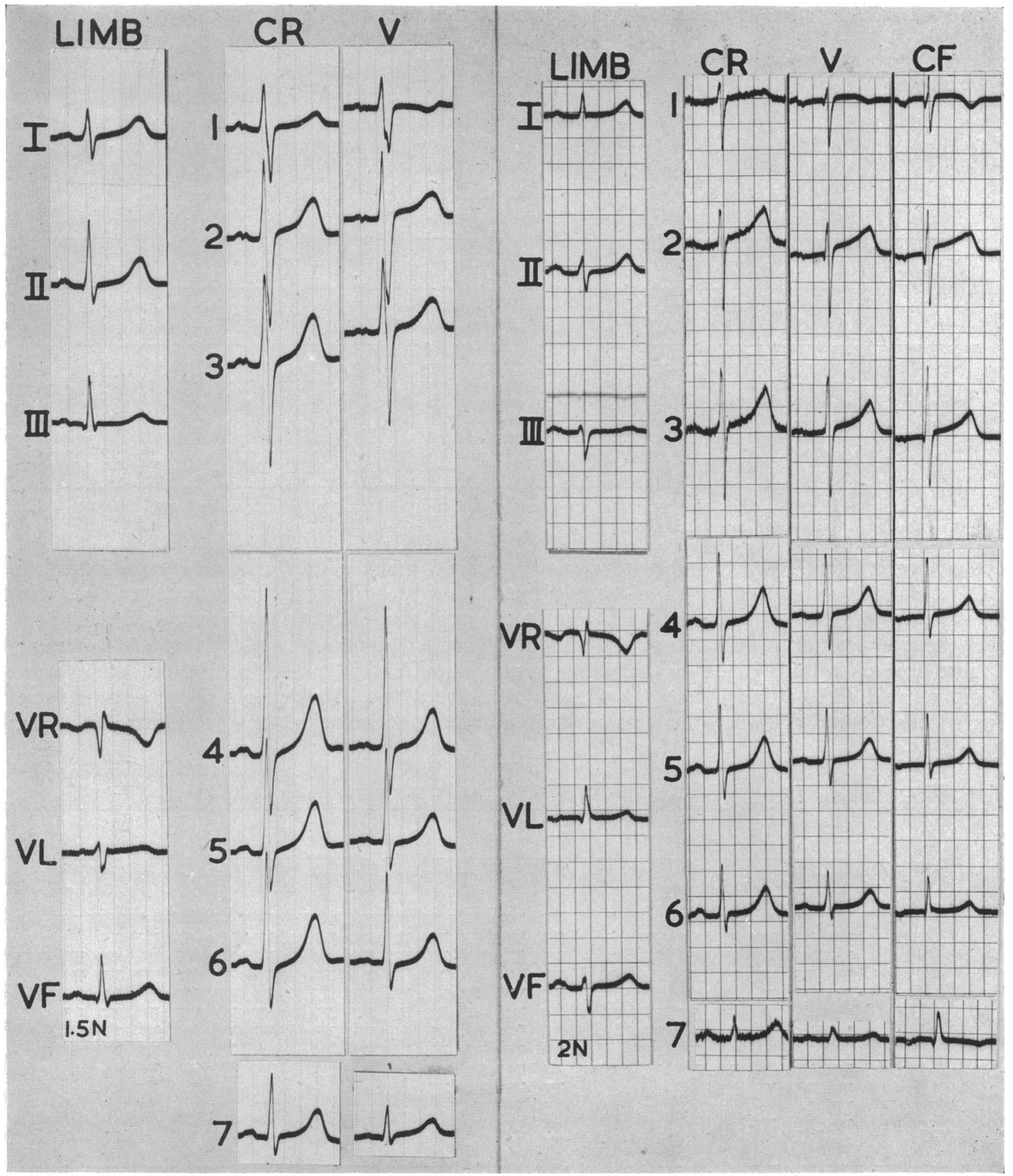

Frg. 1.-Bifid $P$ waves in a man of 20 years. In this and subsequent records the time interval is $1 / 10$ sec., and standardization is normal unless shown to be otherwise.

FIG. 2.-In this man of 71 years there is a small downward deflection in V1 and V2 preceded by a minute initial upward deflection. In CF1, CF2, and CF3 there were small $Q$ waves. In CR1, CR2, and CR3 there were no deflections before the $R$ wave. 
under that heading, but, in three instances, P-R depression of $0.5 \mathrm{~mm}$. was found in CR2 and CR3, and to a less extent in V2 and V3; it was then associated with S-T elevation.

\section{THE Q Wave}

The depth of the $Q$ wave (Table II) was measured to the nearest $0.5 \mathrm{~mm}$; the smallest $\mathrm{Q}$ was regarded as $\mathbf{0 . 2 5} \mathrm{mm}$. deep. The $\mathrm{Q}$ wave never exceeded $4 \mathrm{~mm}$. in leads $\mathrm{Cl}$ to $\mathrm{C} 7$ with any indifferent electrode. In right chest leads $(\mathrm{C} 1$ to $\mathrm{C} 3)$ of the usual pattern with $\mathrm{S}$ greater than $\mathrm{R}$ there

TABLE II

Depth of Q Wave in Healthy Subjects

\begin{tabular}{|c|c|c|c|c|c|c|c|c|c|c|c|c|c|c|c|c|c|c|c|c|c|}
\hline \multirow{3}{*}{$\begin{array}{l}\text { Depth of } \\
\mathbf{Q} \text { in } \mathrm{mm} .\end{array}$} & \multicolumn{7}{|c|}{ CR (100 cases) } & \multicolumn{7}{|c|}{ V (100 cases) } & \multicolumn{7}{|c|}{ CF (50 cases) } \\
\hline & \multicolumn{7}{|c|}{ Chest positions } & \multicolumn{7}{|c|}{ Chest positions } & \multicolumn{7}{|c|}{ Chest positions } \\
\hline & 1 & 2 & 3 & 4 & 5 & 6 & 7 & 1 & 2 & 3 & 4 & 5 & 6 & 7 & 1 & 2 & 3 & 4 & 5 & 6 & 7 \\
\hline 4 & - & - & - & 一 & - & - & - & - & - & 一 & - & - & 1 & - & - & - & - & - & 1 & 1 & 3 \\
\hline $3-4$ & - & 一 & - & 2 & 7 & 7 & 3 & 一 & 一 & 一 & - & 1 & 0 & - & 1 & - & 一 & 1 & 0 & 1 & 3 \\
\hline $2-3$ & - & - & 1 & 10 & 14 & 19 & 15 & - & 一 & - & 3 & 15 & 15 & 4 & 0 & 1 & - & 1 & 3 & 3 & 10 \\
\hline $1-2$ & - & - & 0 & 18 & 35 & 34 & 34 & - & - & - & 21 & 28 & 35 & 35 & 1 & 1 & 2 & 9 & 10 & 14 & 14 \\
\hline $0-1^{*}$ & - & 1 & 7 & 26 & 16 & 21 & 36 & 1 & 2 & 3 & 14 & 27 & 33 & 52 & 0 & 0 & 0 & 3 & 14 & 12 & 8 \\
\hline & 100 & 99 & 92 & 44 & 28 & 19 & 12 & 99 & 98 & 97 & 62 & 29 & 16 & 9 & 48 & 48 & 48 & 36 & 22 & 19 & 12 \\
\hline
\end{tabular}

* Measurements which are a whole number are placed in the range starting with that number, e.g. a subject with a $Q$ of $1 \mathrm{~mm}$. is placed in the $1-2 \mathrm{~mm}$. range.

was never a $Q$ in $C R$ leads, and it was rare or small in $V$ and $C F$ leads. In left chest leads (C5 to C7) a small $Q$ with tall $R$ wave was the rule, but $Q$ was absent in all $C R$ leads in 12 per cent, $V$ in 9 per cent, and CF in 14 per cent, mainly in the older age group; it was never entirely absent from all three series of chest leads in any one person. When a $Q$ appeared in a left chest lead it became more obvious in leads farther to the left, and only disappeared in two subjects in CR and V leads, and in five in CF, but in all these the voltage of $R$ was very low. The depth of $Q$ decreased in some left leads $\mathrm{C} 6$ and $\mathrm{C} 7$ when there was a general decrease in voltage; the $Q / R$ ratio (Table III),

TABLE III

Relation of Depth of $Q$ to Height of $R$ ( $Q / R$ ratio). $Q$ is Expressed as a Percentage of $R$

\begin{tabular}{|c|c|c|c|c|c|c|c|c|c|c|c|c|c|c|c|c|c|c|c|c|c|}
\hline \multirow{2}{*}{$\mathbf{Q} / \mathbf{R}$ ratio } & \multicolumn{7}{|c|}{ CR (100 cases) } & \multicolumn{7}{|c|}{ V (100 cases) } & \multicolumn{7}{|c|}{ CF (50 cases) } \\
\hline & 1 & 2 & $\begin{array}{c}\text { Ches } \\
3\end{array}$ & 4 & 5 & 6 & 7 & 1 & 2 & $\begin{array}{c}\text { Ches } \\
3\end{array}$ & pos & $\begin{array}{c}\text { ition } \\
5\end{array}$ & 6 & 7 & 1 & & $\begin{array}{c}\text { hest } \\
3\end{array}$ & $\begin{array}{c}\text { posi } \\
4\end{array}$ & $\begin{array}{c}\text { tions } \\
5\end{array}$ & 6 & 7 \\
\hline $\begin{array}{c}100+ \\
80-100 \\
60-80 \\
40-60 \\
35-40 \\
30-35 \\
25-30 \\
20-25 \\
15-20 \\
10-15 \\
5-10 \\
1-5\end{array}$ & $\begin{array}{l}z \\
= \\
z \\
z \\
z \\
z \\
-\end{array}$ & $\begin{array}{l}- \\
- \\
- \\
- \\
- \\
- \\
- \\
1\end{array}$ & $\begin{array}{l}- \\
z \\
z \\
z \\
z \\
\frac{1}{7}\end{array}$ & $\begin{array}{l}- \\
- \\
- \\
- \\
- \\
- \\
\overline{3} \\
14 \\
39\end{array}$ & $\begin{array}{l}- \\
- \\
- \\
- \\
- \\
- \\
2 \\
8 \\
34\end{array}$ & $\begin{array}{l}- \\
- \\
\overline{-} \\
- \\
- \\
- \\
-5 \\
11 \\
37 \\
28\end{array}$ & $\begin{array}{l}- \\
- \\
- \\
- \\
-1 \\
2 \\
7 \\
21 \\
40 \\
17\end{array}$ & $\begin{array}{l}z \\
= \\
= \\
= \\
- \\
-\end{array}$ & $\begin{array}{l}\text { Z } \\
\text { - } \\
\text { - } \\
\text { - } \\
\text { E } \\
\frac{2}{2}\end{array}$ & $\begin{array}{l}- \\
= \\
= \\
= \\
- \\
- \\
- \\
3\end{array}$ & $\begin{array}{l}- \\
- \\
- \\
- \\
- \\
- \\
- \\
12 \\
24\end{array}$ & $\begin{array}{l}- \\
= \\
= \\
= \\
\overline{2} \\
1 \\
11 \\
27 \\
30\end{array}$ & $\begin{array}{l}- \\
- \\
- \\
= \\
- \\
-1 \\
7 \\
15 \\
38 \\
22\end{array}$ & $\begin{array}{r}- \\
- \\
- \\
- \\
6 \\
14 \\
10 \\
30 \\
28 \\
3\end{array}$ & $\begin{array}{l}- \\
= \\
z \\
- \\
= \\
= \\
-\end{array}$ & $\begin{array}{l}- \\
= \\
- \\
z \\
- \\
1 \\
-\end{array}$ & $\begin{array}{l}z \\
= \\
z \\
z \\
z \\
z \\
-\end{array}$ & $\begin{array}{l}- \\
= \\
= \\
= \\
= \\
- \\
8 \\
6\end{array}$ & $\begin{array}{l}- \\
- \\
- \\
- \\
- \\
-1 \\
1 \\
6 \\
9 \\
11\end{array}$ & $\begin{array}{r}- \\
- \\
1 \\
1 \\
3 \\
1 \\
2 \\
9 \\
10 \\
4\end{array}$ & $\begin{array}{l}\frac{16}{2} \\
5 \\
2 \\
3 \\
2 \\
5 \\
1 \\
1\end{array}$ \\
\hline
\end{tabular}

however, increased or remained approximately the same from right to left, and $Q$ never exceeded 15 per cent of $R$ in C4, and 30 per cent of $R$ in CR5 to CR7, V5 to V7, and in CF5. Myers (1947) found this figure to be 25 per cent for V1 to V6.

$\mathrm{Q}$ waves occurred with about the same frequency in CR and V leads. They tended to be slightly 
larger in CR because of the higher voltage, but the $Q / R$ ratio was a little larger in $V$. In $V$ leads from the right chest when the $S$ wave was greater than the $R$ wave a $Q$ of $0.25 \mathrm{~mm}$. appeared in three young adults; this was never found in CR leads. In two of these the small Q disappeared in V4 to reappear in leads farther to the left, while in the third the $\mathrm{Q}$ was found in all $\mathrm{V}$ chest leads. In another subject, aged 71 years, a small downward deflection was preceded by a minute initial upward deflection in V1 and V2 (Fig. 2). In CF leads the right chest pattern was modified by $Q$ waves of from a half to three and a half millimetres in four subjects (Fig. 2). In CF6, Q was 50 per cent of $R$ in one subject, and in CF7, 100 per cent or more of $R$ in 16 subjects (Fig. 3), giving $Q / R$ ratios of 50 and 100 per cent or over, respectively.

The width of the $Q$ measured about $0.02 \mathrm{sec}$., and was always less than $0.04 \mathrm{sec}$., as found by Goldberger (1947). There was no difference between the width of Q in CR, CF, and V leads if the depth was comparable. The width of the QRS was found by Myers and others (1947) to range from 0.058 to 0.092 in V1, 0.064 to 0.098 in V2., 0.059 to 0.089 in V5, and 0.062 to 0.098 in V6. The Q-T interval was not measured for each case because, in those examined, it did not differ significantly from published observations on the limb leads (Ashman, 1942; Graybiel and others, 1944; Stewart and Manning 1944).

\section{THE R WAVE}

The QRS complex of the chest lead electrocardiogram has two distinct patterns (Groedel, 1933). Leads taken over the right ventricle consist of a small $r$ and deep $S$ (rS pattern) while leads over the left ventricle have a small $\mathrm{q}$ tall $\mathrm{R}$, and small or absent $\mathrm{s}$ (qRs pattern). Chest leads 1 and 2 usually show the right pattern, 5, 6, and 7, the left pattern, while leads 3 and 4 may be either pattern or a mixture of the two (Fig. 4); obviously there is no constant pattern for individual chest positions because the relationship of the heart to the chest wall is variable. Myers (1947) found no R in V1 in 4, and in V2 in 2, out of 25 healthy subjects. In the present series the $R$ wave in $C 1$ was often small (Table IV) but it was never absent in CR or V. From right to left there was usually a progres-

TABLE IV

Height of R Wave in Healthy Subjects

\begin{tabular}{|c|c|c|c|c|c|c|c|c|c|c|c|c|c|c|c|c|c|c|c|c|c|}
\hline \multirow{2}{*}{$\begin{array}{l}\text { Height of } \mathbf{R} \\
\text { in } \mathrm{mm} \text {. }\end{array}$} & \multicolumn{7}{|c|}{ CR (100 cases) } & \multicolumn{7}{|c|}{ V (100 cases) } & \multicolumn{7}{|c|}{ CF (50 cases) } \\
\hline & 1 & 2 & $\begin{array}{c}\text { Ches } \\
\mathbf{3}\end{array}$ & $\begin{array}{c}\text { pos } \\
4\end{array}$ & $\begin{array}{l}\text { ition } \\
5\end{array}$ & s 6 & 7 & 1 & 2 & \multicolumn{3}{|c|}{ Chest positions } & s 6 & 7 & 1 & & $\begin{array}{c}\text { Chest } \\
3\end{array}$ & $\begin{array}{c}\text { posi } \\
\end{array}$ & $\begin{array}{c}\text { ition } \\
5\end{array}$ & 6 & 7 \\
\hline $\begin{array}{l}55-60 \\
50-55 \\
45-50 \\
40-45 \\
35-40 \\
30-35 \\
25-30 \\
20-25 \\
15-20 \\
10-15 \\
9-10 \\
8-9 \\
7-8 \\
6-7 \\
5-6 \\
4-5 \\
3-4 \\
2-3 \\
1-2 \\
0-1 \\
0\end{array}$ & $\begin{array}{l}\bar{Z} \\
\bar{Z} \\
\overline{-} \\
\overline{-} \\
\overline{-} \\
\overline{-} \\
1 \\
2 \\
1 \\
2 \\
9 \\
13 \\
20 \\
19 \\
22 \\
11 \\
-\end{array}$ & $\begin{array}{r}- \\
\text { - } \\
- \\
- \\
- \\
- \\
6 \\
24 \\
11 \\
9 \\
10 \\
7 \\
9 \\
8 \\
7 \\
6 \\
3 \\
-\end{array}$ & $\begin{array}{r}- \\
- \\
1 \\
0 \\
3 \\
2 \\
12 \\
19 \\
27 \\
9 \\
4 \\
7 \\
5 \\
3 \\
2 \\
4 \\
1 \\
1 \\
- \\
-\end{array}$ & $\begin{array}{r}1 \\
2 \\
3 \\
4 \\
6 \\
9 \\
25 \\
14 \\
22 \\
11 \\
0 \\
3 \\
- \\
- \\
- \\
- \\
- \\
-\end{array}$ & $\begin{array}{r}- \\
\overline{-} \\
4 \\
7 \\
9 \\
15 \\
25 \\
26 \\
10 \\
2 \\
0 \\
2 \\
- \\
- \\
- \\
- \\
- \\
-\end{array}$ & $\begin{array}{r}- \\
1 \\
1 \\
2 \\
8 \\
9 \\
28 \\
24 \\
23 \\
1 \\
2 \\
0 \\
1 \\
- \\
- \\
- \\
- \\
-\end{array}$ & $\begin{array}{r}- \\
- \\
- \\
1 \\
0 \\
3 \\
20 \\
45 \\
10 \\
3 \\
8 \\
6 \\
1 \\
2 \\
1 \\
- \\
- \\
-\end{array}$ & $\begin{array}{l}- \\
- \\
- \\
- \\
- \\
- \\
- \\
- \\
- \\
\\
3 \\
3 \\
6 \\
14 \\
23 \\
32 \\
16 \\
3 \\
-\end{array}$ & $\begin{array}{r}- \\
- \\
- \\
- \\
- \\
- \\
- \\
\overline{13} \\
6 \\
11 \\
11 \\
18 \\
7 \\
8 \\
10 \\
12 \\
3 \\
1 \\
-\end{array}$ & $\begin{array}{r}- \\
- \\
- \\
-1 \\
2 \\
1 \\
8 \\
31 \\
7 \\
5 \\
13 \\
7 \\
8 \\
6 \\
6 \\
4 \\
0 \\
1 \\
\end{array}$ & $\begin{array}{r}- \\
1 \\
1 \\
1 \\
9 \\
7 \\
25 \\
23 \\
19 \\
2 \\
3 \\
6 \\
3 \\
- \\
- \\
- \\
- \\
-\end{array}$ & $\begin{array}{r}- \\
- \\
-1 \\
1 \\
5 \\
5 \\
17 \\
29 \\
28 \\
5 \\
5 \\
2 \\
2 \\
1 \\
- \\
- \\
- \\
-\end{array}$ & $\begin{array}{r}- \\
- \\
- \\
1 \\
2 \\
2 \\
7 \\
16 \\
41 \\
8 \\
12 \\
7 \\
2 \\
1 \\
1 \\
- \\
- \\
- \\
-\end{array}$ & $\begin{array}{r}- \\
- \\
\bar{Z} \\
- \\
- \\
- \\
1 \\
0 \\
8 \\
3 \\
11 \\
10 \\
9 \\
29 \\
7 \\
14 \\
6 \\
1 \\
1 \\
-\end{array}$ & $\begin{array}{l}- \\
- \\
- \\
- \\
- \\
- \\
- \\
- \\
- \\
- \\
- \\
- \\
2 \\
1 \\
3 \\
9 \\
14 \\
18 \\
2 \\
1\end{array}$ & $\begin{array}{l}- \\
\overline{-} \\
\overline{-} \\
- \\
\overline{-} \\
\overline{-} \\
\overline{-} \\
4 \\
1 \\
3 \\
5 \\
9 \\
2 \\
7 \\
6 \\
7 \\
5 \\
1 \\
-\end{array}$ & $\begin{array}{r}- \\
- \\
- \\
\overline{-} \\
- \\
- \\
1 \\
1 \\
12 \\
2 \\
2 \\
4 \\
1 \\
5 \\
5 \\
10 \\
5 \\
2 \\
-\end{array}$ & $\begin{array}{r}\text { - } \\
2 \\
1 \\
3 \\
4 \\
11 \\
12 \\
1 \\
4 \\
4 \\
4 \\
1 \\
1 \\
2 \\
- \\
- \\
-\end{array}$ & $\begin{array}{r}\text { - } \\
\text { 二 } \\
\text { - } \\
1 \\
0 \\
5 \\
6 \\
14 \\
5 \\
4 \\
4 \\
5 \\
3 \\
0 \\
3 \\
- \\
- \\
-\end{array}$ & $\begin{array}{r}\text { 二 } \\
\text { - } \\
- \\
-1 \\
1 \\
2 \\
3 \\
9 \\
0 \\
2 \\
11 \\
3 \\
3 \\
5 \\
6 \\
3 \\
2 \\
-\end{array}$ & $\begin{array}{r}\overline{-} \\
- \\
- \\
- \\
= \\
- \\
\overline{-} \\
2 \\
0 \\
0 \\
1 \\
3 \\
2 \\
5 \\
5 \\
10 \\
11 \\
5 \\
6\end{array}$ \\
\hline Mean height & $3 \cdot 8$ & $8 \cdot 0$ & $13 \cdot 3$ & 27 & $22 \cdot 6$ & $20 \cdot 0$ & $12 \cdot 0$ & $2 \cdot 9$ & $6 \cdot 1$ & $9 \cdot 4$ & 18 & 716 & $513 \cdot$ & 35.9 & $2 \cdot 2$ & $5 \cdot 0$ & $6 \cdot 8$ & 14 & 411 & $48 \cdot 0$ & 2.9 \\
\hline
\end{tabular}




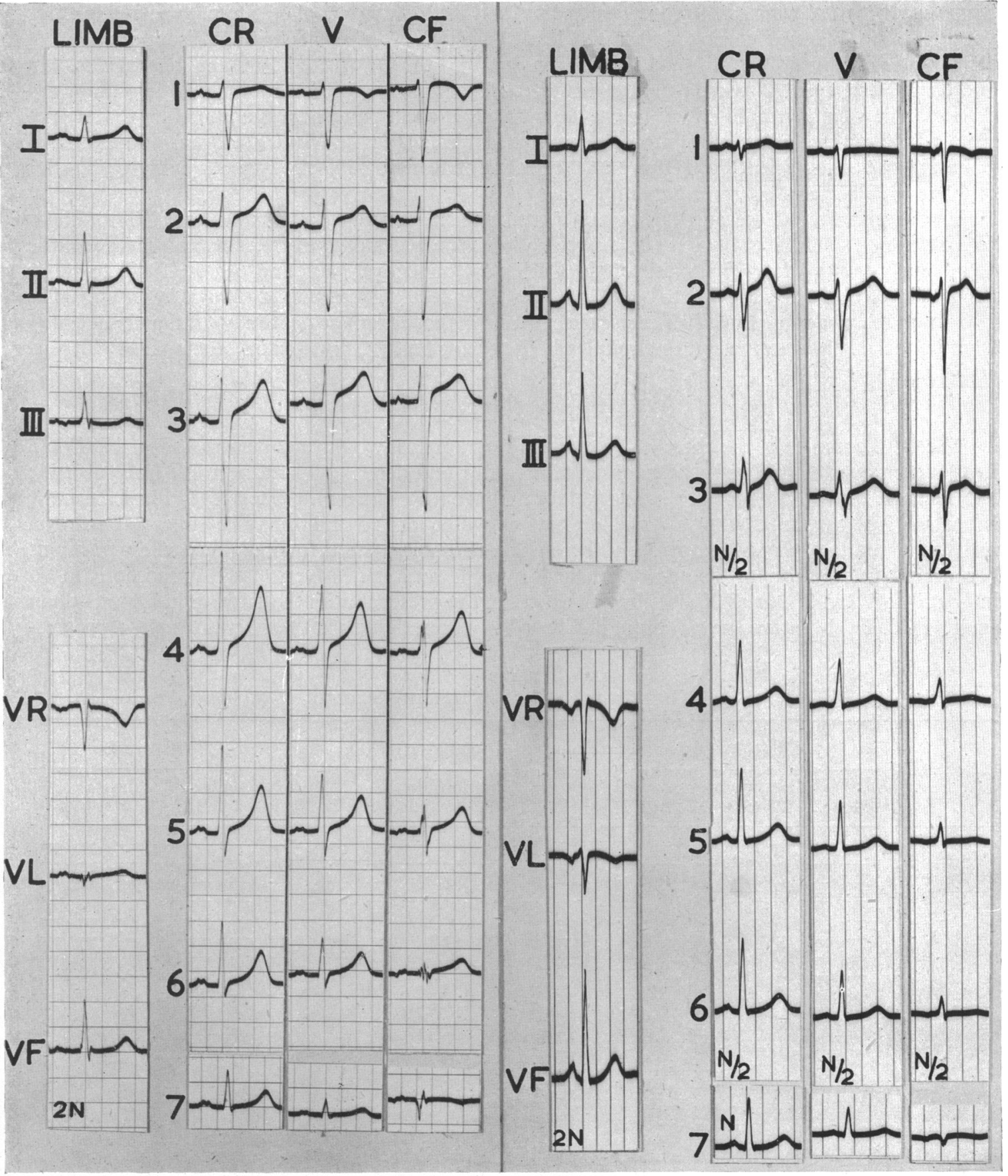

FIG. 3.-The $Q$ wave is relatively large in CF7.

FIG. 4.-In this man of 44 years chest leads 1 and 2 show the right pattern, leads $4,5,6$, and 7 show the left pattern, while 3 is intermediate. There is no $Q$ wave until C7. 


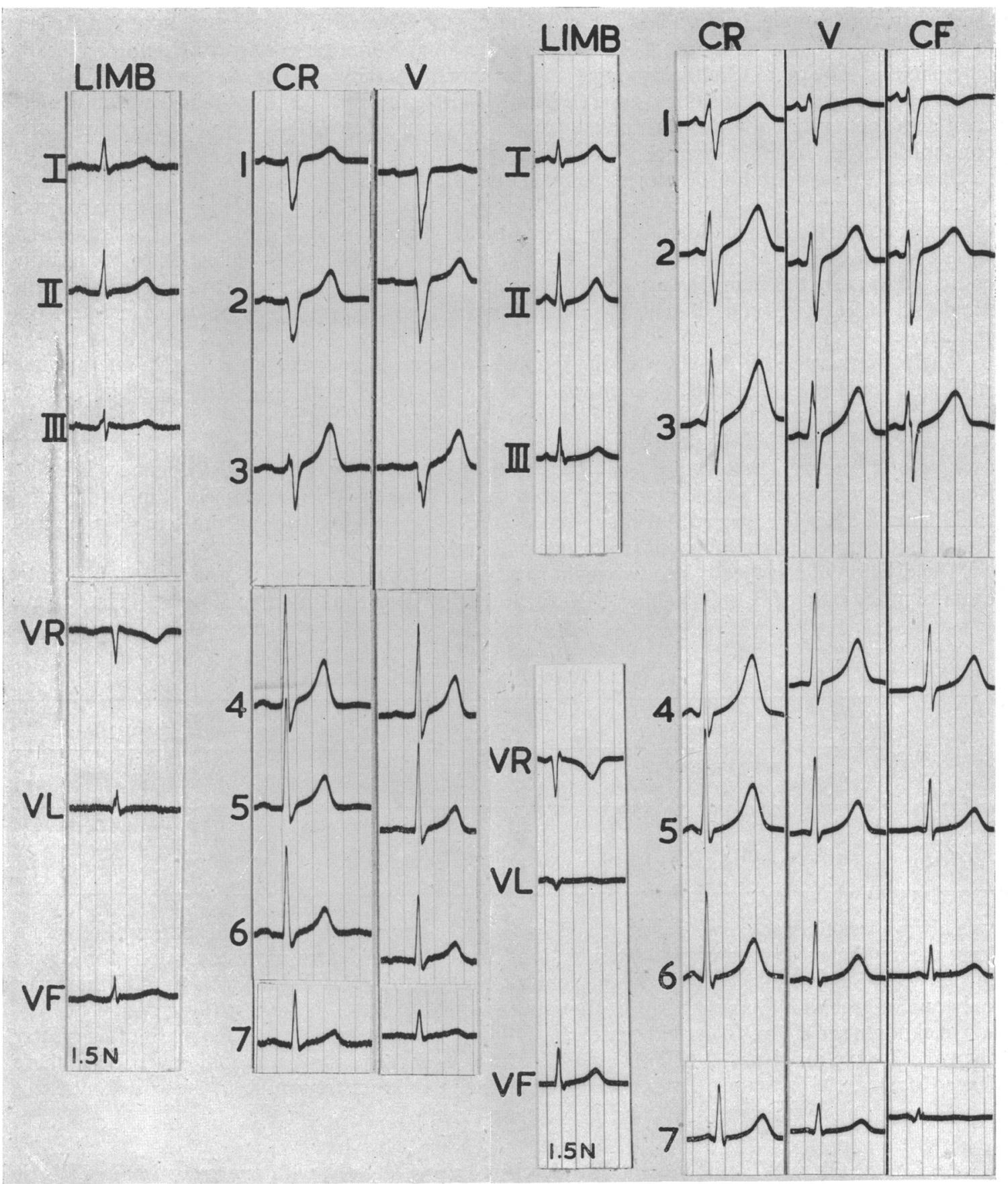

Fig. 5.-The $R$ wave is the same height in V1, V2, and $V 3$, in this man of 34 years.

FIG. 6.-Slurring of $\mathbf{R}$ or $\mathbf{S}$ in leads from the right chest and transitional zone in this man of 21 years. 
sive increase in the height of the $\mathrm{R}$ wave to a peak in $\mathrm{C} 4$, sometimes in $\mathrm{C} 3, \mathrm{C} 5$, or $\mathrm{C} 6$ decreasing in size again in leads farther to the left. In a few instances the $\mathrm{R}$ wave was the same height in several chest leads, for example, in V1, V2, V3 (Fig. 5); rarely the R wave fell 1 or $2 \mathrm{~mm}$. in a lead farther to the left, but this might have been due to respiratory variation. There were no significant differences in the size of $\mathbf{R}$ in the two age groups. Slurring of any part of $\mathbf{R}$ or $\mathbf{S}$ occurred in leads from the right chest or transitional zone (Wilson, 1947), as in Fig. 6, but not in leads from the left chest showing a qRs pattern in this investigation. A second $R$ wave $\left(R^{\prime}\right)$ following the $S$ was quite common in leads from the right chest, particularly at a high level (Fig. 9). An $\mathbf{R}^{\prime}$ wave in $\mathrm{Cl}$, or in $\mathrm{C} 1$ and $\mathrm{C} 2$, was found in 11 subjects (Fig. 7 and 10). The $\mathrm{R}^{\prime}$ was small and less than $\mathrm{R}$ except when carried higher by S-T elevation in one instance, and in CF1 only in another; in these subjects there was no slurred $S$ in standard lead 1 or chest lead 7, while in a 21-year-old medical student, $S$ was slurred in I, II, and C5 and C6, not in C7; but there was no $\mathrm{R}^{\prime}$ in $\mathrm{C1}$. In one otherwise healthy man aged 41 years the $R^{\prime}$ in $C 1$ was slightly taller than $R$ and was associated with a slurred $S$ in leads I and $\mathrm{C} 4$ to $\mathrm{C} 7$; he was considered to have partial right bundle branch block and was excluded from the series.

The $R$ wave varied in height with the indifferent electrode and was tallest in $C R$, intermediate in $\mathrm{V}$, and shortest in CF leads, with one exception where the $\mathrm{R}$ wave measured $1 \mathrm{~mm}$. in CR1 to CR3 and $1.5 \mathrm{~mm}$. in V1 to V3 (Fig. 8) and several exceptions in right CF leads. In CR4 the R wave varied in height from 8 to $60 \mathrm{~mm}$. with an average of $25 \mathrm{~mm}$., and in V4 from 6 to $50 \mathrm{~mm}$. with an average of $19 \mathrm{~mm}$. These values are higher than those found by Myers (1947), namely R in V4 from 2 to $25 \mathrm{~mm}$., average $13.0 \mathrm{~mm}$. in 52 subjects, and by Dolgin (1949), namely R in V4 from 5.8 to $27.1 \mathrm{~mm}$., average $14.6 \mathrm{~mm}$. in 44 subjects. In CF4 the $R$ wave varied from 4 to $45 \mathrm{~mm}$., and Katz (1946) suggested a minimal normal value of $3 \mathrm{~mm}$. for this lead.

The division of chest leads into two main patterns, $\mathrm{rS}$ on the right and $\mathrm{qRs}$ on the left, is seen by examining the ratio of $R$ to $S$ (Table $V$ ). The clearest division took place in $V$ leads. The $R$ wave

TABLE V

Ratio of R to S in Healthy Subjects

\begin{tabular}{|c|c|c|c|c|c|c|c|c|c|c|c|c|c|c|c|c|c|c|c|c|c|}
\hline \multirow{3}{*}{$\mathrm{R} / \mathrm{S}$ ratio } & \multicolumn{7}{|c|}{ CR (100 cases) } & \multicolumn{7}{|c|}{ V (100 cases) } & \multicolumn{7}{|c|}{ CF (50 cases) } \\
\hline & \multicolumn{7}{|c|}{ Chest positions } & \multicolumn{7}{|c|}{ Chest positions } & \multicolumn{7}{|c|}{ Chest positions } \\
\hline & 1 & 2 & 3 & 4 & 5 & 6 & 7 & 1 & 2 & 3 & 4 & 5 & 6 & 7 & 1 & 2 & 3 & 4 & 5 & 6 & 7 \\
\hline $\begin{array}{l}\mathbf{R}>\mathbf{S} \\
\mathbf{R}=\mathbf{S} \\
\mathbf{R}<\mathbf{S}\end{array}$ & $\begin{array}{r}6 \\
4 \\
90\end{array}$ & $\begin{array}{r}15 \\
5 \\
80\end{array}$ & $\begin{array}{r}50 \\
2 \\
48\end{array}$ & $\begin{array}{r}95 \\
1 \\
4\end{array}$ & $\begin{array}{r}98 \\
0 \\
2\end{array}$ & $\begin{array}{r}99 \\
0 \\
1\end{array}$ & $\begin{array}{r}99 \\
0 \\
1\end{array}$ & $\begin{array}{r}0 \\
0 \\
100\end{array}$ & $\begin{array}{r}5 \\
0 \\
95\end{array}$ & $\begin{array}{r}21 \\
6 \\
73\end{array}$ & $\begin{array}{r}90 \\
1 \\
9\end{array}$ & $\begin{array}{r}97 \\
1 \\
2\end{array}$ & $\begin{array}{r}99 \\
0 \\
1\end{array}$ & $\begin{array}{r}99 \\
0 \\
1\end{array}$ & $\begin{array}{r}1 \\
0 \\
49\end{array}$ & $\begin{array}{r}0 \\
0 \\
50\end{array}$ & $\begin{array}{r}6 \\
2 \\
42\end{array}$ & $\begin{array}{r}41 \\
3 \\
6\end{array}$ & $\begin{array}{r}49 \\
0 \\
1\end{array}$ & $\begin{array}{r}44 \\
2 \\
4\end{array}$ & $\begin{array}{r}37 \\
6 \\
7\end{array}$ \\
\hline
\end{tabular}

was always less than the S wave in V1, and was greater than S in V7 in all but one subject with a long narrow heart on radiological examination. In CR1 there were more exceptions for $R$ was greater than $S$ in six subjects (Fig. 9), but in most of these the voltage was low. In CR7 there was only one subject with S greater than R, the same as in V7.

In children the $R / S$ ratio in right chest leads is different from adults, for the $R$ wave is often greater than the $\mathrm{S}$ wave in V1 or V2 (Fig. 11 and 12, p. 224), and there may be steep $\mathrm{T}$ inversion in these leads (Master, 1937; Suarez, 1946). Left chest leads in children are similar to those in adults.

\section{THE S WAVE}

An S wave (Table VI) was present in right chest leads $\mathrm{C} 1$ to $\mathrm{C3}$, with one exception in $\mathrm{CF} 1$; it was greater than $R$ in most subjects, and always so in V1. It usually reached its maximum depth in $\mathrm{C} 2$ but not till $\mathrm{C} 3$ in about one-third of the older and one-sixth of the younger group, and in CR4 and CF4 in one subject. The $\mathrm{S}$ wave was deep in some subjects, reaching a maximum of $35 \mathrm{~mm}$. in .CR and V, and $40 \mathrm{~mm}$. in CF leads. It diminished progressively to the left, but occasionally 


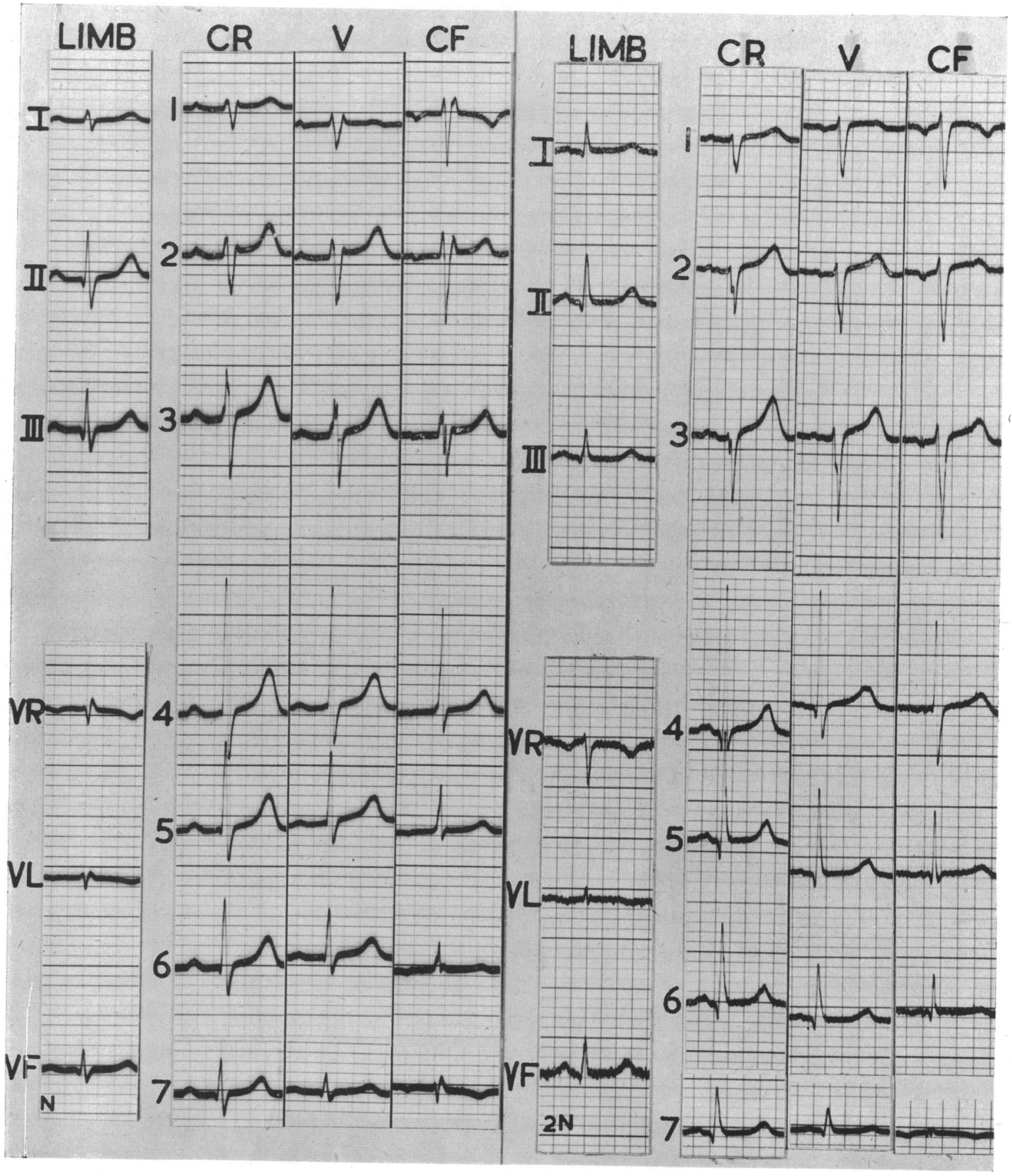

Fig. 7. $-R^{\prime}$ in $C 1$ and $C 2$ in this man of 41 years.

FIG. 8.-The $R$ wave was usually tallest in $C R$ leads, intermediate in $\mathrm{V}$, and shortest in $\mathrm{CF}$, but in this man, aged 59 years, $R$ was shortest in CR1, CR2, and $\mathbf{C R} 3$. 


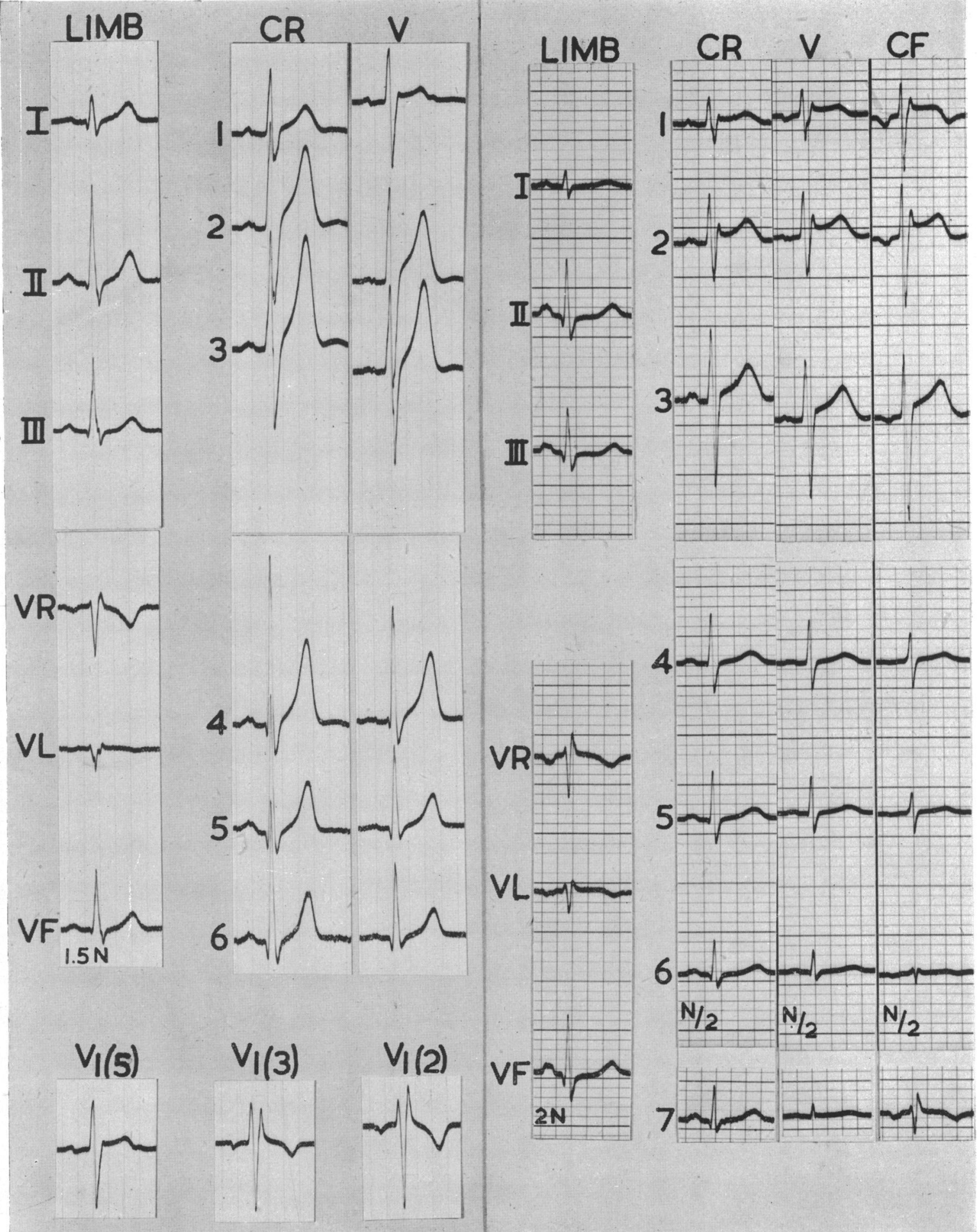

FIG. 9.- In this man of 24 years (not in the series) $R$ is greater than $S$ in CR1, but not in V1. There is an $\mathbf{R}^{\prime}$ in $\mathrm{V} 1$ taken in the second and third intercostal spaces, but it is very small in standard V1, or in V1

FIG. 10.-S-T elevation in leads from the right chest in a man of 61 years. There is an $R^{\prime}$ in $\mathrm{Cl}$ and $\mathrm{C} 2$. in the fifth space. 
remained at the same height and rarely increased slightly though by less than $1 \mathrm{~mm}$. In left chest leads $\mathrm{S}$ was comparatively small and often absent, but once in CR6 and CR7, once in V6 and V7, and often in CF6 and CF7, it was greater than R.

In right chest leads $S$ was deepest in $C F$, intermediate in $V$ and least deep in $C R$, but in left chest leads $\mathbf{S}$ was often deepest in $\mathrm{CR}$.

TABLE VI

Depth of S Wave in Healthy Subjects

\begin{tabular}{|c|c|c|c|c|c|c|c|c|c|c|c|c|c|c|c|c|c|c|c|c|c|}
\hline \multirow{2}{*}{$\begin{array}{l}\text { Depth of } \\
\mathbf{S} \text { in } \mathrm{mm} .\end{array}$} & \multicolumn{7}{|c|}{ CR (100 cases) } & \multicolumn{7}{|c|}{ V (100 cases) } & \multicolumn{7}{|c|}{ CF (50 cases) } \\
\hline & 1 & $2^{C}$ & $\begin{array}{c}\text { Chest } \\
3\end{array}$ & posit $_{4}$ & $\begin{array}{l}\text { itions } \\
5\end{array}$ & 6 & 7 & 1 & $2^{C}$ & $\begin{array}{c}\text { Chest } \\
3\end{array}$ & posi & $\begin{array}{l}\text { itions } \\
5\end{array}$ & s 6 & 7 & 1 & $2^{C}$ & Thest & $\begin{array}{l}\text { posit } \\
4\end{array}$ & $\begin{array}{l}\text { tions } \\
5\end{array}$ & 6 & 7 \\
\hline $\begin{array}{c}35-40 \\
30-35 \\
25-30 \\
20-25 \\
15-20 \\
10-15 \\
5-10 \\
4-5 \\
3-4 \\
2-3 \\
1-2 \\
0\end{array}$ & $\begin{array}{r}= \\
\bar{Z} \\
3 \\
28 \\
53 \\
10 \\
1 \\
5 \\
-\end{array}$ & $\begin{array}{l}\overline{1} \\
1 \\
6 \\
30 \\
35 \\
27 \\
= \\
= \\
\overline{-}\end{array}$ & $\begin{array}{r}- \\
3 \\
10 \\
16 \\
37 \\
27 \\
3 \\
2 \\
2 \\
-\end{array}$ & $\begin{array}{r}- \\
= \\
\overline{2} \\
18 \\
37 \\
12 \\
9 \\
11 \\
6 \\
5\end{array}$ & $\begin{array}{l}= \\
\bar{Z} \\
\overline{1} \\
1 \\
17 \\
13 \\
19 \\
14 \\
20 \\
15\end{array}$ & $\begin{array}{l}= \\
\bar{Z} \\
\overline{-} \\
1 \\
7 \\
4 \\
17 \\
26 \\
20 \\
25\end{array}$ & $\begin{array}{l}= \\
= \\
= \\
\overline{1} \\
1 \\
1 \\
15 \\
43 \\
39\end{array}$ & $\begin{array}{r}- \\
1 \\
0 \\
14 \\
37 \\
40 \\
7 \\
1 \\
= \\
=\end{array}$ & $\begin{array}{r}\overline{2} \\
2 \\
18 \\
31 \\
26 \\
20 \\
1 \\
= \\
= \\
-\end{array}$ & $\begin{array}{r}- \\
4 \\
13 \\
21 \\
32 \\
26 \\
1 \\
1 \\
2 \\
=\end{array}$ & $\begin{array}{r}\overline{ } \\
\bar{Z} \\
\overline{7} \\
15 \\
41 \\
10 \\
12 \\
10 \\
6 \\
5\end{array}$ & $\begin{array}{l}= \\
\bar{z} \\
\bar{z} \\
\overline{12} \\
13 \\
14 \\
27 \\
16 \\
18\end{array}$ & $\begin{array}{l}\bar{E} \\
\bar{Z} \\
\overline{-} \\
2 \\
1 \\
10 \\
20 \\
39 \\
28\end{array}$ & $\begin{array}{l}= \\
\bar{Z} \\
\bar{Z} \\
\bar{z} \\
\overline{2} \\
35 \\
63\end{array}$ & $\begin{array}{r}- \\
1 \\
7 \\
11 \\
19 \\
9 \\
2 \\
= \\
\overline{1}\end{array}$ & $\begin{array}{r}1 \\
1 \\
1 \\
13 \\
15 \\
13 \\
5 \\
0 \\
1 \\
= \\
-\end{array}$ & $\begin{array}{l}= \\
4 \\
6 \\
11 \\
14 \\
15 \\
= \\
= \\
=\end{array}$ & $\begin{array}{r}- \\
\bar{Z} \\
2 \\
9 \\
16 \\
10 \\
3 \\
7 \\
1 \\
2\end{array}$ & $\begin{array}{l}= \\
= \\
= \\
\bar{Z} \\
11 \\
5 \\
6 \\
13 \\
8 \\
7\end{array}$ & $\begin{array}{l}= \\
\bar{Z} \\
\bar{Z} \\
\overline{2} \\
2 \\
4 \\
3 \\
10 \\
16 \\
15\end{array}$ & $\begin{array}{l}= \\
\bar{Z} \\
= \\
\bar{Z} \\
2 \\
1 \\
4 \\
9 \\
34\end{array}$ \\
\hline Mean depth & $7 \cdot 8$ & $13 \cdot 1$ & $12 \cdot 6$ & $6 \cdot 1$ & $3 \cdot 0$ & $2 \cdot 0$ & 0.8 & $10 \cdot 1$ & 114.9 & $13 \cdot 3$ & $5 \cdot 8$ & 2.5 & $1 \cdot 3$ & 0.2 & & $16 \cdot 7$ & 14.4 & 6.0 & $2 \cdot 9$ & $1 \cdot 5$ & \\
\hline
\end{tabular}

\section{S-T Deviation}

The level of the S-T segment was taken $1 \mathrm{~mm}$. after the termination of the QRS complex, and its deviation from the iso-electric line (T-P interval) was measured to the nearest millimetre (Table VII). Deviation of less than $0.5 \mathrm{~mm}$. was not noted.

TABLE VII

S-T Deviation in Healthy Subjects

\begin{tabular}{|c|c|c|c|c|c|c|c|c|c|c|c|c|c|c|c|c|c|c|c|c|c|}
\hline \multirow{2}{*}{$\begin{array}{l}\text { S-T deviation } \\
\text { in } \mathrm{mm} \text {. }\end{array}$} & \multicolumn{7}{|c|}{ CR (100 cases) } & \multicolumn{7}{|c|}{ V (100 cases) } & \multicolumn{7}{|c|}{ CF (50 cases) } \\
\hline & 1 & 2 & Chest & pos & ition & 6 & 7 & 1 & & Ches & & tion & 6 & 7 & 1 & 2 & hes & ${ }_{4}^{\text {pos }}$ & $\begin{array}{c}\text { itions } \\
5\end{array}$ & 6 & 7 \\
\hline \multirow[t]{2}{*}{$\begin{array}{l}S-T \text { eleva- } \\
\text { tion }\end{array}$} & $\bar{z}$ & $\begin{array}{r}1 \\
7 \\
64\end{array}$ & $\begin{array}{r}1 \\
6 \\
48\end{array}$ & $\begin{array}{r}-6 \\
29\end{array}$ & $\begin{array}{r} \\
3 \\
19\end{array}$ & $\begin{array}{r}2 \\
16\end{array}$ & $\begin{array}{l}1 \\
5\end{array}$ & $\overline{-}$ & $\begin{array}{r}2 \\
8 \\
65\end{array}$ & $\begin{array}{r}1 \\
7 \\
56\end{array}$ & $\begin{array}{r}-4 \\
28\end{array}$ & $\overline{1}$ & $\overline{-}$ & $\overline{-}$ & $\begin{array}{r}-2 \\
34\end{array}$ & $\begin{array}{r}-6 \\
34\end{array}$ & $\begin{array}{r}\overline{4} \\
28\end{array}$ & $\begin{array}{r}\overline{1} \\
17\end{array}$ & $\overline{1}$ & $\overline{7}$ & $\overline{-}$ \\
\hline & 57 & 23 & 40 & 59 & 73 & 77 & 90 & 52 & 24 & 32 & 63 & 83 & 88 & 95 & 14 & 10 & 18 & 32 & 44 & 44 & 49 \\
\hline \multirow{2}{*}{$\begin{array}{l}\text { S-T depres- } \\
\text { sion }\end{array}$} & 4 & 5 & 4 & 4 & 4 & 4 & 4 & - & 1 & 4 & 5 & 4 & 3 & 2 & - & - & - & - & - & 一 & 一 \\
\hline & - & - & 1 & 2 & 1 & 1 & - & - & - & - & - & - & - & - & - & - & - & - & - & - & - \\
\hline
\end{tabular}

S-T elevation (Fig. 10) was found frequently in leads from the right chest especially with high voltage and it reached $3 \mathrm{~mm}$. in two subjects. It was about the same for CR and V leads, but was less in CF. In shape the raised S-T segment was straight or concave upwards ending in an upright $T$ wave, in CR and V leads, as pointed out by Myers (1947).

S-T depression was much less common and it varied with the indifferent electrode employed. It was greatest in CR leads reaching $2 \mathrm{~mm}$. in two young women with tachycardia (rates 120 and 


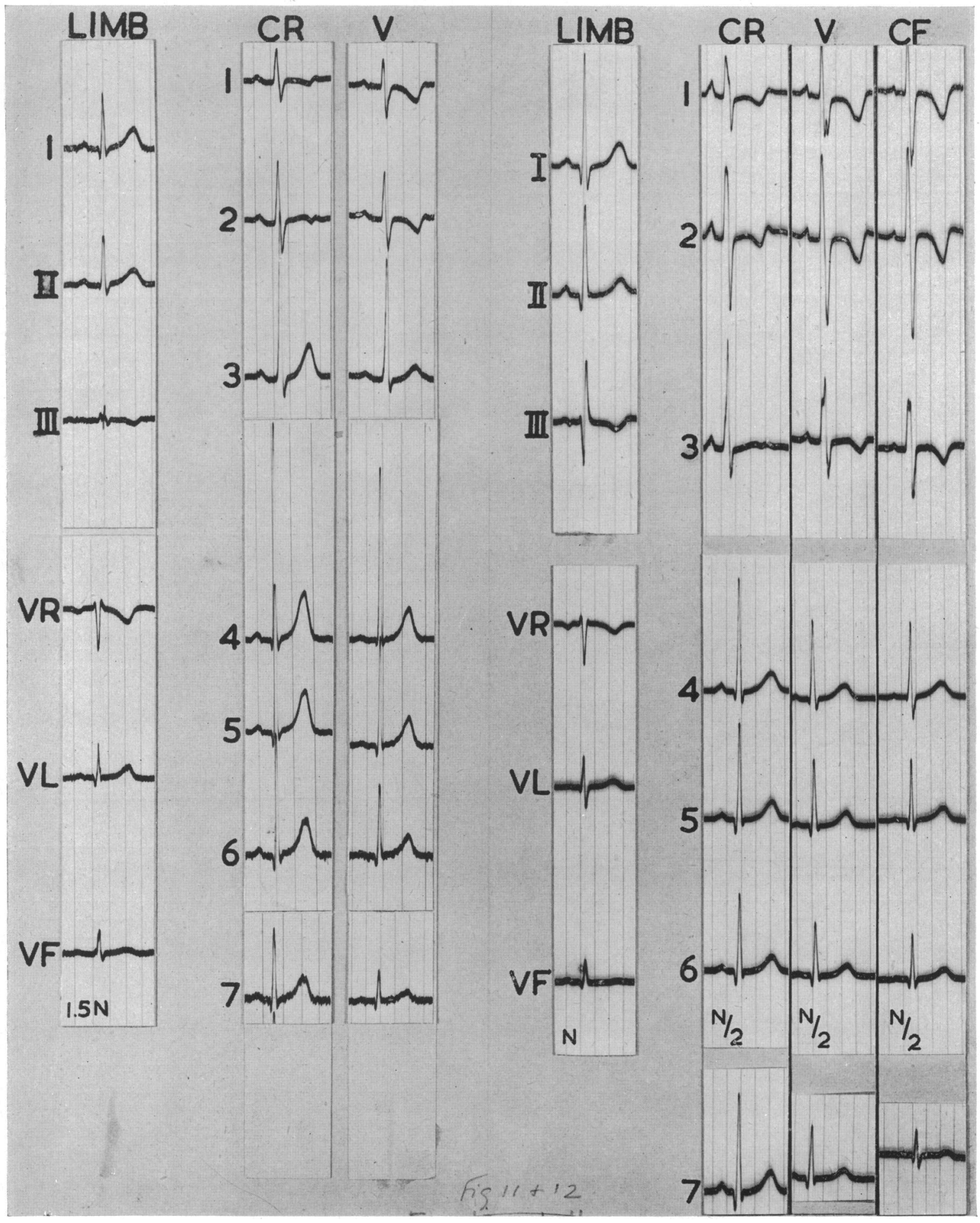

Fig. 11 and 12. $-\mathrm{R}$ is equal or larger than $\mathrm{S}$ with steep $\mathrm{T}$ inversion in $\mathrm{Cl}$ and $\mathrm{C} 2$ in these children aged five years. 
115 a minute) and depression of the P-R interval (Fig. 13). With a short diastole the $P$ wave fell on the descending limb of the preceding $\mathrm{T}$ wave so that the $\mathrm{T}-\mathrm{P}$ interval was raised causing apparent depression of the P-R and S-T segments in relation to the T-P reference level. S-T depression of 0.5 to $1.0 \mathrm{~mm}$. in CR leads was found in six subjects chiefly affecting the left chest leads; in four there was tachycardia and consequent P-R depression also; in two the S-T depression was accompanied by slight $\mathrm{P}-\mathrm{R}$ depression without tachycardia. In $\mathrm{V}$ leads $\mathrm{S}-\mathrm{T}$ depression not exceeding $1.0 \mathrm{~mm}$. was found in five subjects of whom four had tachycardia with $\mathrm{P}-\mathrm{R}$ depression, and one slight P-R and S-T depression without tachycardia. In CF leads S-T deviation was minimal, for similar deviation at the left foot (VF in Fig. 13) cancelled out changes at the chest electrode. These changes agree with those found by Myers (1947) who stated that depression of the RS-T junction was very rare in the præcordial leads in health and that it should be regarded as abnormal if it was $0.5 \mathrm{~mm}$. or greater, provided that tachycardia or a prominent auricular $\mathrm{T}$ wave was absent.

\section{THE T WAVE}

In right chest leads the $T$ wave was sometimes very tall reaching $18 \mathrm{~mm}$. in $C R, 16 \mathrm{~mm}$. in $\mathrm{V}$, and $15 \mathrm{~mm}$. in CF (Table VIII), it was often taller than the $R$ wave. In left leads of $\mathrm{qR}$ or qRs pattern the $T$ averaged about one-quarter of the height of $R$ for any of the indifferent electrodes. With a

TABLE VIII

Height of T Wave in Healthy Subjects

\begin{tabular}{|c|c|c|c|c|c|c|c|c|c|c|c|c|c|c|c|c|c|c|c|c|c|}
\hline \multirow{2}{*}{$\begin{array}{l}\text { Height or depth } \\
\text { of } \mathrm{T} \text { in } \mathrm{mm} \text {. }\end{array}$} & \multicolumn{7}{|c|}{ CR (100 cases) } & \multicolumn{7}{|c|}{ V (100 cases) } & \multicolumn{7}{|c|}{ CF (50 cases) } \\
\hline & 1 & $2^{C}$ & Ch & $\mathrm{p}$ & 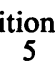 & 6 & 7 & 1 & $2^{C}$ & $\begin{array}{c}\text { Chest } \\
\mathbf{3}\end{array}$ & $\frac{\text { pos }}{4}$ & & 6 & 7 & 1 & 2 & $\begin{array}{c}\text { Chest } \\
3\end{array}$ & 4 & 5 & s 6 & 7 \\
\hline $\begin{array}{c}18- \\
17-18 \\
16-17 \\
15-16 \\
14-15 \\
13-14 \\
12-13 \\
11-12 \\
10-11 \\
9-10 \\
8-9 \\
7-8 \\
6-7 \\
5-6 \\
4-5 \\
3-4 \\
2-3 \\
1-2 \\
0.5-1 \\
0 \\
-0 \cdot 5-1 \\
-1-2 \\
-2-3 \\
-3-4 \\
-4\end{array}$ & $\begin{array}{l}- \\
- \\
- \\
- \\
- \\
- \\
- \\
- \\
-3 \\
1 \\
4 \\
9 \\
18 \\
20 \\
27 \\
17 \\
1 \\
- \\
- \\
- \\
-\end{array}$ & $\begin{array}{r}1 \\
0 \\
1 \\
4 \\
3 \\
5 \\
2 \\
8 \\
7 \\
8 \\
14 \\
8 \\
12 \\
13 \\
10 \\
3 \\
0 \\
1 \\
- \\
- \\
- \\
- \\
\end{array}$ & $\begin{array}{r}2 \\
2 \\
3 \\
1 \\
4 \\
5 \\
8 \\
6 \\
8 \\
11 \\
14 \\
10 \\
12 \\
5 \\
5 \\
3 \\
0 \\
1 \\
- \\
- \\
- \\
-\end{array}$ & $\begin{array}{r}-1 \\
1 \\
3 \\
3 \\
2 \\
6 \\
4 \\
8 \\
6 \\
16 \\
14 \\
9 \\
9 \\
10 \\
5 \\
2 \\
1 \\
- \\
- \\
- \\
-\end{array}$ & $\begin{array}{l}-1 \\
1 \\
0 \\
0 \\
0 \\
1 \\
3 \\
4 \\
8 \\
8 \\
16 \\
18 \\
10 \\
13 \\
10 \\
7 \\
- \\
- \\
- \\
- \\
- \\
-\end{array}$ & $\begin{array}{l}- \\
- \\
- \\
- \\
- \\
3 \\
0 \\
5 \\
5 \\
3 \\
6 \\
18 \\
17 \\
19 \\
15 \\
9 \\
- \\
- \\
- \\
- \\
-\end{array}$ & $\begin{array}{l}- \\
- \\
- \\
- \\
- \\
- \\
- \\
- \\
- \\
1 \\
15 \\
15 \\
26 \\
34 \\
- \\
- \\
- \\
-\end{array}$ & $\begin{array}{l}- \\
- \\
- \\
- \\
- \\
- \\
- \\
- \\
- \\
1 \\
2 \\
7 \\
3 \\
9 \\
19 \\
29 \\
3 \\
8 \\
4 \\
15 \\
- \\
-\end{array}$ & $\begin{array}{r}- \\
- \\
1 \\
1 \\
2 \\
2 \\
5 \\
8 \\
5 \\
9 \\
9 \\
12 \\
10 \\
15 \\
12 \\
7 \\
2 \\
- \\
- \\
- \\
- \\
-\end{array}$ & $\begin{array}{r}- \\
- \\
- \\
2 \\
2 \\
5 \\
5 \\
10 \\
9 \\
6 \\
11 \\
19 \\
11 \\
13 \\
2 \\
4 \\
1 \\
- \\
- \\
- \\
- \\
-\end{array}$ & $\begin{array}{r}- \\
- \\
- \\
1 \\
0 \\
3 \\
4 \\
3 \\
3 \\
10 \\
9 \\
19 \\
14 \\
12 \\
13 \\
7 \\
2 \\
- \\
- \\
- \\
\\
-\end{array}$ & $\begin{array}{r}- \\
- \\
- \\
-1 \\
1 \\
0 \\
1 \\
0 \\
0 \\
3 \\
6 \\
17 \\
13 \\
21 \\
16 \\
17 \\
5 \\
- \\
- \\
- \\
- \\
-\end{array}$ & $\begin{array}{r}- \\
- \\
- \\
- \\
- \\
- \\
- \\
-1 \\
1 \\
4 \\
6 \\
7 \\
18 \\
24 \\
31 \\
8 \\
- \\
- \\
- \\
-\end{array}$ & $\begin{array}{l}- \\
- \\
- \\
- \\
- \\
- \\
- \\
- \\
- \\
- \\
- \\
- \\
-6 \\
28 \\
57 \\
-7 \\
1 \\
- \\
-\end{array}$ & $\begin{array}{r}- \\
- \\
- \\
- \\
- \\
- \\
- \\
- \\
- \\
- \\
- \\
- \\
- \\
-1 \\
3 \\
5 \\
4 \\
0 \\
2 \\
1 \\
19 \\
11 \\
3 \\
1\end{array}$ & $\begin{array}{r}- \\
- \\
- \\
- \\
33 \\
0 \\
0 \\
2 \\
1 \\
5 \\
4 \\
9 \\
5 \\
4 \\
3 \\
11 \\
0 \\
1 \\
0 \\
0 \\
1 \\
1 \\
-\end{array}$ & $\begin{array}{c}- \\
- \\
- \\
-1 \\
0 \\
0 \\
3 \\
3 \\
3 \\
5 \\
6 \\
3 \\
7 \\
9 \\
7 \\
1 \\
1 \\
0 \\
1 \\
- \\
- \\
- \\
-\end{array}$ & $\begin{array}{l}- \\
- \\
- \\
- \\
-1 \\
1 \\
1 \\
2 \\
3 \\
3 \\
5 \\
8 \\
12 \\
7 \\
2 \\
6 \\
- \\
- \\
- \\
- \\
- \\
-\end{array}$ & $\begin{array}{l}- \\
\bar{Z} \\
\bar{Z} \\
- \\
\bar{Z} \\
\overline{-} \\
\overline{-} \\
1 \\
1 \\
0 \\
3 \\
5 \\
7 \\
10 \\
12 \\
10 \\
0 \\
1 \\
- \\
- \\
- \\
-\end{array}$ & $\begin{array}{r}- \\
- \\
- \\
- \\
- \\
- \\
- \\
- \\
- \\
- \\
1 \\
3 \\
2 \\
2 \\
14 \\
21 \\
3 \\
2 \\
1 \\
1 \\
- \\
-\end{array}$ & $\begin{array}{r}- \\
- \\
- \\
- \\
- \\
- \\
- \\
- \\
- \\
- \\
- \\
- \\
- \\
- \\
- \\
1 \\
4 \\
3 \\
8 \\
9 \\
20 \\
4 \\
0 \\
1\end{array}$ \\
\hline Mean height & $3 \cdot 5$ & $8 \cdot 2$ & $9 \cdot 2$ & $7 \cdot 9$ & $6 \cdot 3$ & $5 \cdot 4$ & $3 \cdot 3$ & $1 \cdot 5$ & $6 \cdot 5$ & $7 \cdot 1$ & $5 \cdot 8$ & $4 \cdot 4$ & $3 \cdot 4$ & $1 \cdot 5$ & 0.6 & $5 \cdot 3$ & $6 \cdot 0$ & $4 \cdot 7$ & $3 \cdot 3$ & $1 \cdot 7$ & -0.5 \\
\hline
\end{tabular}

general decrease in voltage as may occur from $\mathrm{C} 5$ to $\mathrm{C} 6$ and $\mathrm{C} 7$ the $\mathrm{T} / \mathrm{R}$ ratio remained about the same. T was always more than one-twelfth and rarely exceeded three-quarters of $R$ (Table IX) in left pattern CR and V leads with the exception of two subjects with flat or inverted T waves in V7. There was little difference in the $\mathrm{T}$ wave in the two age groups in CR leads, but in V1 the $\mathrm{T}$ was more often inverted in the younger group. In children the $\mathrm{T}$ is frequently inverted in $\mathrm{Cl}$ and other right 


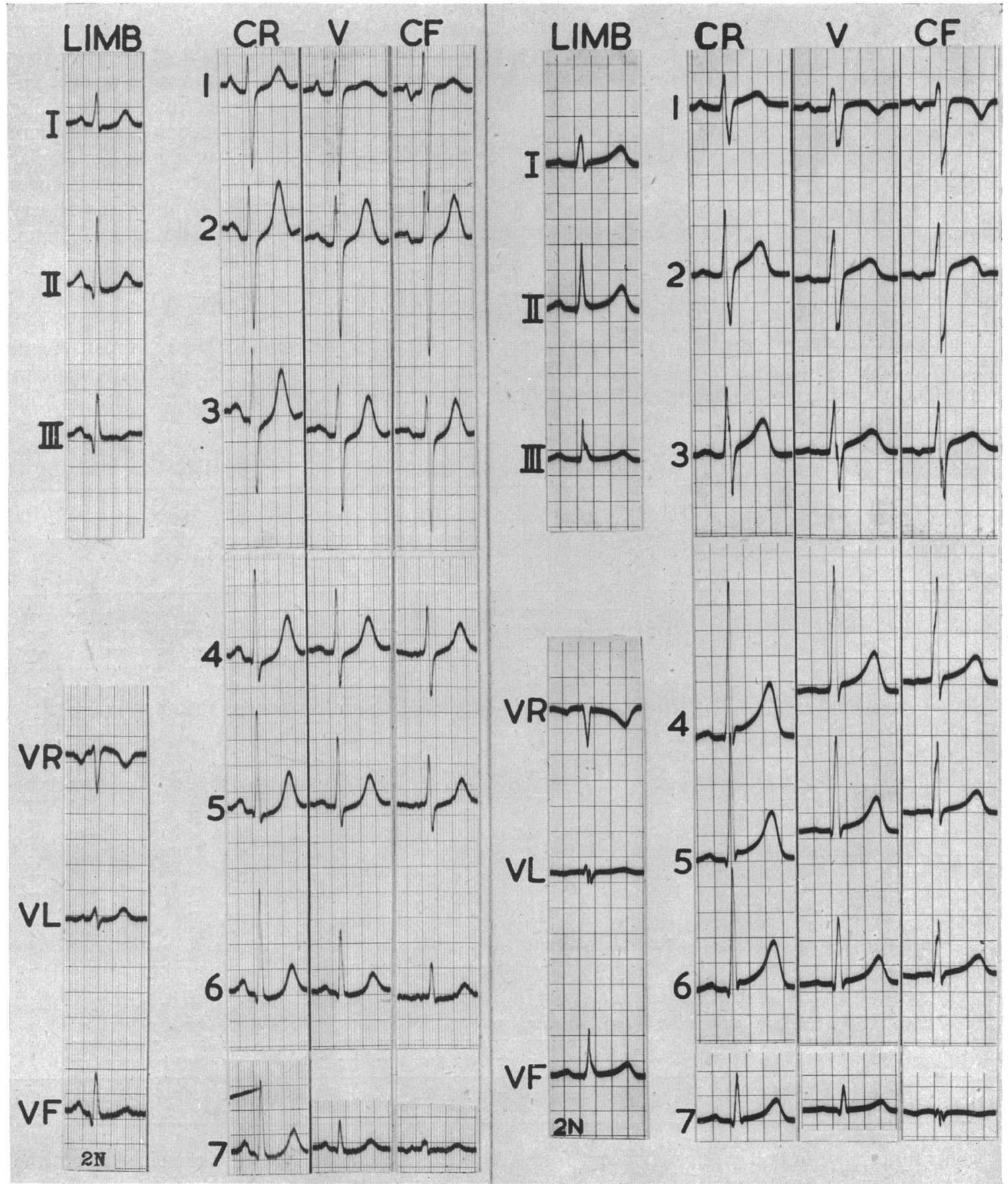

Fio. 13.-P-R and S-T depression from tachycardia (rate 120) in a pregnant woman aged 32 years.

FIG. 14.-T wave inversion in V1 and in CF1, but not in $C R 1$, in this man of 28 years. 
chest leads (Fig. 11 and 12) as shown by Master (1937) and Suarez (1946). In shape the T wave showed a gradual rise with an upward concavity (Myers and others, 1947) to the peak when it fell steeply to the iso-electric level. It was symmetrical only in the few subjects showing $\mathrm{S}-\mathrm{T}$ depression. Its peak was never bifid but in one man of 49 years it was flat.

The height of the $T$ wave varied with the indifferent electrode and was greatest in CR, intermediate in V, and least in CF leads. From CR1 to CR7 the T wave was always upright in the 100

TABLE IX

Ratio of Height of $T$ to Height of $R$ (T/R Ratio) in Left Chest Leads when $S$ is Less than One-Quarter of $R$ and $T$ is Positive. $T$ is Expressed as a Percentage of $R$

\begin{tabular}{|c|c|c|c|c|c|c|c|c|c|c|c|c|}
\hline \multirow{2}{*}{$T / R$ ratio } & \multicolumn{4}{|c|}{ CR (100 cases) } & \multicolumn{4}{|c|}{ V (100 cases) } & \multicolumn{4}{|c|}{ CF (50 cases) } \\
\hline & \multicolumn{4}{|c|}{ Chest positions } & 4 & \multicolumn{2}{|c|}{ Chest positions } & 7 & 4 & \multicolumn{2}{|c|}{ Chest positions } & 7 \\
\hline $\begin{array}{l}90-100 \\
80-90 \\
70-80 \\
60-70 \\
50-60 \\
40-50 \\
30-40 \\
20-30 \\
10-20 \\
9-10 \\
8-9 \\
7-8 \\
6-7 \\
5-6 \\
4-5\end{array}$ & $\begin{array}{r}- \\
- \\
1 \\
2 \\
4 \\
19 \\
23 \\
12 \\
1 \\
2 \\
- \\
- \\
-\end{array}$ & $\begin{array}{r}- \\
- \\
3 \\
2 \\
6 \\
19 \\
27 \\
22 \\
2 \\
1 \\
- \\
-\end{array}$ & $\begin{array}{l}- \\
- \\
- \\
2 \\
11 \\
15 \\
32 \\
23 \\
0 \\
2 \\
- \\
- \\
-\end{array}$ & $\begin{array}{l}- \\
1 \\
2 \\
10 \\
11 \\
14 \\
28 \\
28 \\
- \\
- \\
- \\
-\end{array}$ & $\begin{array}{l}- \\
- \\
- \\
2 \\
2 \\
11 \\
16 \\
9 \\
- \\
- \\
- \\
-\end{array}$ & $\begin{array}{r}- \\
- \\
\overline{-} \\
2 \\
6 \\
15 \\
21 \\
26 \\
1 \\
1 \\
- \\
-\end{array}$ & $\begin{array}{l}- \\
- \\
\bar{Z} \\
2 \\
7 \\
17 \\
22 \\
33 \\
- \\
- \\
- \\
-\end{array}$ & $\begin{array}{r}1 \\
1 \\
0 \\
1 \\
3 \\
14 \\
17 \\
30 \\
24 \\
0 \\
2 \\
- \\
- \\
-\end{array}$ & $\begin{array}{l}- \\
= \\
- \\
- \\
-2 \\
4 \\
4 \\
- \\
- \\
-\end{array}$ & $\begin{array}{l}1 \\
0 \\
0 \\
1 \\
0 \\
3 \\
5 \\
6 \\
6 \\
1 \\
1 \\
1 \\
0 \\
1 \\
-\end{array}$ & $\begin{array}{r}- \\
1 \\
0 \\
1 \\
1 \\
3 \\
6 \\
10 \\
0 \\
3 \\
1 \\
0 \\
1 \\
1\end{array}$ & $\begin{array}{l}- \\
\text { - } \\
- \\
- \\
2 \\
2 \\
1 \\
0 \\
1 \\
- \\
-\end{array}$ \\
\hline Mean ratio & 26 & 28 & 27 & 29 & 27 & 23 & 25 & 28 & 23 & 27 & 21 & 23 \\
\hline
\end{tabular}

adults, but an isoelectric or slightly inverted $\mathrm{T}$ in CR1 occurs occasionally in younger adults. In left CR leads T was lowest in CR7 with a minimum height of $1 \mathrm{~mm}$. but not low in relation to the $R$ wave for it was never less than one-tenth of $R$. The $T$ wave in $V$ was always lower than in $C R$ leads. It was inverted in V1 (Fig. 14) in 19 of the 100 subjects (12 in the younger group and 7 in the older), but it was always upright in V2; in every instance of $\mathrm{T}$ inversion in V1 a right pattern chest lead with $S$ greater than or about equal to $R$ with an upright $T$ was found in $V 2$. The $T$ wave was upright in V2 to V6, but it was often low in V7 when R was low, and it was once flat (Fig. 15) and once inverted by $0.5 \mathrm{~mm}$. In V6 the $\mathrm{T}$ was never less than 10 per cent of $R$, and in V7 with an upright $T$ wave never less than 8 per cent of $R$. Myers (1947) found inversion of the $T$ wave in VI in 7 of 16 cases, in V2 in three women aged 19, 31, and 45 years, out of 52 cases; he found a flat $T$ in V3 once and in V6 once; he did not mention V7. In CF1 the T wave was inverted in 35 of the 50 subjects, in CF2 in two, and T was flat once in CF3. With one exception a right chest lead with S greater than $R$ and upright $T$ wave was found in CF3, if not in CF1, or CF2. The $T$ wave was usually inverted in CF7, twice inverted in CF6 (Fig. 16), and once flat in CF5; it was always upright in CF4, but its inversion in health in this lead has been found by others (Sodeman, 1937; Graybiel, 1944; Katz, 1948).

\section{Comparison of CR, CF, AND V Chest Leads}

While the British Cardiac Society have recently (1949) recommended the central terminal (V), there is still no universal agreement on any one indifferent electrode in chest lead electrocardiography and many clinicians may continue to use the chest lead to which they are most accustomed until another lead is shown to have practical advantages. Leaving theoretical considerations aside, the best chest lead is the one which varies least in health and shows the earliest changes in disease. 


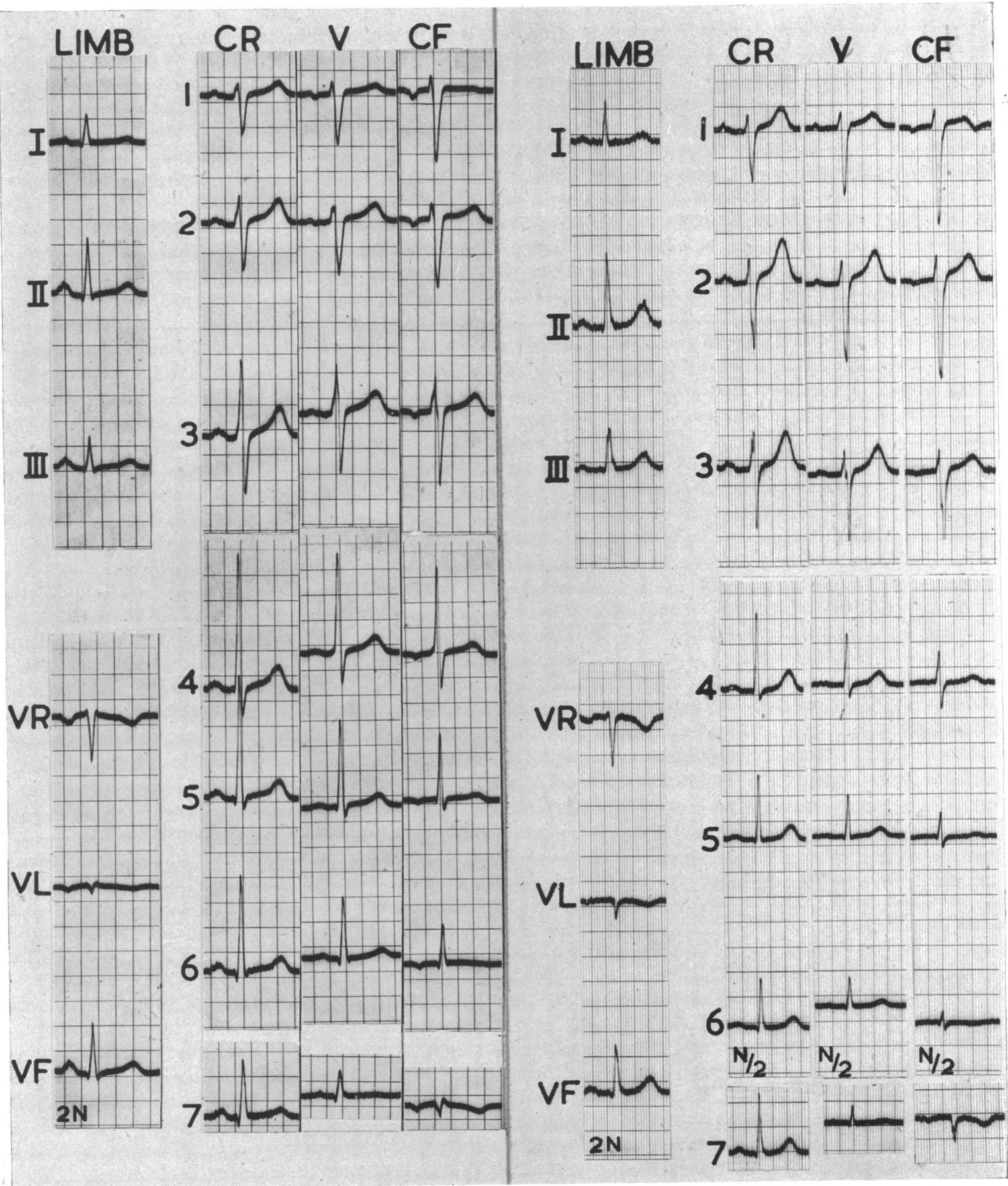

Fig. 15.-Flat $\mathrm{T}$ in $\mathrm{V} 7$ in a man of 62 years.

Fig. 16.-Low $\mathrm{T}$ wave in CF5 and inversion in CF6 and CF7 in a man of 45 years. 
Normal variations in CF leads are very great, compared with those in CR and V leads. These variations are shown in Table $X$ where the coefficients of variations for the $R$, and $T$ waves in CF leads are usually much greater than in CR and V leads. Normal T wave inversion in CF leads is another disadvantage. CF leads are said to be more sensitive in detecting minor abnormalities from coronary artery disease, but it is probable that most of these minor abnormalities fall within their wide limits of normal variation. These are due to the great changes in potential at the indifferent electrode on the left foot with changes in position of the heart. They make CF leads unsuitable for routine use.

Chest leads would be truly unipolar if the indifferent electrode were at zero potential This has not yet been achieved (Eckey and Fröhlich, 1938) but the central terminal (V) is the nearest approach (Wilson, 1934; Burger, 1939). An equally good indifferent electrode for practical, though not for theoretical, purposes is one with a constant potential so that the same error is always introduced. The right arm indifferent electrode (CR) is a close approach to this. Whether the central terminal is less variable than the right arm has yet to be determined. Groedel (1948) believes that the central terminal is unduly influenced by the left foot which is so variable. In this investigation it was found that $C R$ and $V$ chest leads have very similar coefficients of variation for the $R, S$, and $T$ waves (Table X) in most leads. V leads show less S-T segment deviation (Table VII) and a clearer division

TABLE X

Mean Values, Standard Deviations, and Coffficients of Variation, for the R, S, and T Waves of 50 SUBJects OVER 40 YeARS OF AGE

\begin{tabular}{|c|c|c|c|c|c|c|c|c|c|}
\hline \multirow[t]{2}{*}{$\begin{array}{l}\text { Chest } \\
\text { position }\end{array}$} & \multicolumn{3}{|c|}{ Mean } & \multicolumn{3}{|c|}{$\begin{array}{l}\text { Standard } \\
\text { deviation }\end{array}$} & \multicolumn{3}{|c|}{$\begin{array}{l}\text { Coefficient of } \\
\text { variation }\end{array}$} \\
\hline & CR & $\mathbf{V}$ & CF & CR & $\mathbf{V}$ & $\mathrm{CF}$ & CR & V & CF \\
\hline $\begin{array}{l}1 \\
2 \\
3 \\
4 \\
5 \\
6 \\
7\end{array}$ & $\begin{array}{r}3.0 \\
6.6 \\
12.3 \\
24.0 \\
21.6 \\
19.0 \\
10.7\end{array}$ & $\begin{array}{r}2.2 \\
5.2 \\
9.0 \\
19.0 \\
16.0 \\
13.0 \\
5.1\end{array}$ & $\begin{array}{r}2.2 \\
5.0 \\
6.8 \\
14.4 \\
11.4 \\
8.0 \\
2.6\end{array}$ & $\begin{array}{r}1.5 \\
3.8 \\
8.0 \\
11.0 \\
8.4 \\
8.9 \\
5.0\end{array}$ & $\begin{array}{c}R \text { wave } \\
1.0 \\
2.9 \\
6.0 \\
9.0 \\
7.0 \\
7.0 \\
3.2\end{array}$ & $\begin{array}{l}1 \cdot 4 \\
2 \cdot 8 \\
4 \cdot 5 \\
8 \cdot 1 \\
5 \cdot 8 \\
6 \cdot 0 \\
2 \cdot 5\end{array}$ & $\begin{array}{l}49 \\
58 \\
65 \\
46 \\
39 \\
47 \\
47\end{array}$ & $\begin{array}{l}46 \\
55 \\
66 \\
47 \\
42 \\
54 \\
63\end{array}$ & $\begin{array}{l}62 \\
57 \\
67 \\
57 \\
51 \\
74 \\
95\end{array}$ \\
\hline $\begin{array}{l}1 \\
2 \\
3 \\
4 \\
5 \\
6 \\
7\end{array}$ & $\begin{array}{r}7 \cdot 7 \\
12.8 \\
12.7 \\
6.6 \\
3.3 \\
2.1 \\
0.8\end{array}$ & $\begin{array}{r}9.8 \\
14.0 \\
13.2 \\
6.0 \\
2.6 \\
1.5 \\
0.2\end{array}$ & $\begin{array}{r}13.3 \\
16.7 \\
14.4 \\
6.0 \\
3.0 \\
1.5 \\
0.5\end{array}$ & $\begin{array}{l}2 \cdot 9 \\
5 \cdot 0 \\
5 \cdot 0 \\
4 \cdot 1 \\
3 \cdot 2 \\
2 \cdot 2 \\
1 \cdot 1\end{array}$ & $\begin{array}{c}S \text { wave } \\
3.8 \\
5.3 \\
5.2 \\
4.0 \\
2.2 \\
1.5 \\
0.3\end{array}$ & $\begin{array}{l}5 \cdot 4 \\
6 \cdot 5 \\
6 \cdot 2 \\
3 \cdot 5 \\
2.4 \\
1.9 \\
1 \cdot 1\end{array}$ & $\begin{array}{r}38 \\
39 \\
41 \\
62 \\
99 \\
108 \\
131\end{array}$ & $\begin{array}{r}39 \\
38 \\
39 \\
58 \\
86 \\
106 \\
170\end{array}$ & $\begin{array}{r}41 \\
40 \\
43 \\
60 \\
81 \\
125 \\
202\end{array}$ \\
\hline $\begin{array}{l}1 \\
2 \\
3 \\
4 \\
5 \\
6 \\
7\end{array}$ & $\begin{array}{l}3 \cdot 3 \\
8 \cdot 6 \\
9 \cdot 8 \\
8.6 \\
6 \cdot 8 \\
5 \cdot 7 \\
3 \cdot 2\end{array}$ & $\begin{array}{l}1 \cdot 6 \\
6 \cdot 8 \\
7 \cdot 7 \\
6 \cdot 5 \\
4 \cdot 7 \\
3 \cdot 6 \\
1 \cdot 3\end{array}$ & $\begin{array}{r}0.6 \\
5.3 \\
6.0 \\
4.7 \\
3.3 \\
1.7 \\
-0.5\end{array}$ & $\begin{array}{l}1.6 \\
4.0 \\
4.0 \\
3.7 \\
2.9 \\
2.6 \\
1.4\end{array}$ & $\begin{array}{c}T w a \\
1.7 \\
3.5 \\
3.1 \\
3.0 \\
2.1 \\
1.8 \\
0.8\end{array}$ & $\begin{array}{l}1.8 \\
3.3 \\
3.0 \\
2.5 \\
2.5 \\
1.4 \\
1.1\end{array}$ & $\begin{array}{l}50 \\
47 \\
40 \\
43 \\
42 \\
45 \\
43\end{array}$ & $\begin{array}{r}111 \\
51 \\
40 \\
46 \\
46 \\
49 \\
61\end{array}$ & $\begin{array}{r}329 \\
62 \\
49 \\
52 \\
75 \\
82 \\
206\end{array}$ \\
\hline
\end{tabular}

into right and left patterns, but normal $\mathrm{T}$ wave inversion in $\mathrm{V} 1$, and rarely in $\mathrm{V7}$, is perhaps a disadvantage. Thus neither lead has shown much advantage over the other in this investigation.

SUMmary AND CONCLUSIONS

Standard limb leads, unipolar limb leads, and chest leads CR1 to CR7 and V1 to V7 were taken Q 
in 100 healthy adults, and leads CF1 to CF7 were taken in the first 50 (older group). Measurements of the $P, Q, R, S$, and $T$ waves, and of the $S-T$ segment, together with $Q / R, R / S$, and $T / R$ ratios are shown in simple distribution tables. Standard deviations and coefficients of variation are given for the R, S, and T waves in the older group of 50 subjects. The extreme limits for the electrocardiogram in health cannot be given from the examination of 100 subjects. The trend of the frequency distribution shows that the probability of a measurement falling much outside the range of these observations must be small.

The $P$ wave which remained about the same height in leads $\mathrm{Cl}$ to $\mathrm{C} 7$ and was sometimes bifid, was most positive in CR leads, and was rarely more than $2 \mathrm{~mm}$., or less than $0.5 \mathrm{~mm}$. in height. In $\mathrm{V} 1$ and V2 $\mathrm{P}$ might be $1 \mathrm{~mm}$. negative; in V3 to V7 it was isoelectric or positive, not exceeding $1.5 \mathrm{~mm}$. in height. In CF leads $P$ was usually isoelectric or negative.

The $Q$ wave did not exceed $4 \mathrm{~mm}$. with any indifferent electrode. In right chest leads when $\mathrm{S}$ was greater than $R$ there was no $Q$ wave except in rare instances in $V$ leads when there was a $Q$ of $0.25 \mathrm{~mm}$., or in CF leads when it was slightly larger.

In left chest leads a $Q$ wave was found in 90 per cent of persons examined, but it was less than one-seventh of $R$ in C4, and one-third of $R$ in C5 to C7, excepting CF6 and CF7. When a $Q$ appeared in a chest lead its ratio to $R$ increased in leads farther to the left, except in rare instances of very low voltage.

The $R$ and $S$ waves. The $\mathrm{R}$ wave was very small in right $\mathrm{CR}$ and $\mathrm{V}$ chest leads, but it was always present in this series. It increased in height, rarely remaining the same, in leads farther to the left to a peak usually at $\mathrm{C} 4$, then decreased again towards $\mathrm{C7}$. The $\mathrm{R}$ wave was usually tallest in $\mathrm{CR}$. leads, intermediate in V, shortest in CF. The $S$ wave was deepest in CF, intermediate in $V$, and least in CR, in right leads, but it was often deepest in CR in left leads. $R$ was less than $S$ in V1, and, with some exceptions, in CR1; $R$ was greater than $S$ in $C R 7$ and V7 with one exception. In children $\mathrm{R}$ may be greater than $\mathrm{S}$ in $\mathrm{C} 1$ or $\mathrm{C} 2$ and there may be steep $\mathrm{T}$ inversion in these leads.

A second $\mathrm{R}$ wave sometimes occurred in $\mathrm{C} 1$ or $\mathrm{C} 2$, but it was small and less than the first $\mathrm{R}$.

Slurring of $R$ was not seen in left leads of $q R$ or $q R s$ pattern, but was frequent in right leads or in the transitional zone.

$S-T$ elevation reached $3 \mathrm{~mm}$. in leads from the right chest, especially with a high voltage $S$ wave. In shape it was straight or concave upwards ending in an upright $\mathrm{T}$ wave in CR and V leads.

$S-T$ depression greater than $0.5 \mathrm{~mm}$. below the T-P level was not seen in chest leads in the absence of tachycardia and depression of the P-R segment or, more rarely, of P-R depression alone. S-T depression was greatest in CR, intermediate in V, least in CF leads.

The $T$ wave was often very tall in right leads reaching $18 \mathrm{~mm}$. in CR, $16 \mathrm{~mm}$. in V, and $15 \mathrm{~mm}$. in $C F$ leads, often exceeding the $R$ wave. In left leads the $T$ averaged about one-quarter of the height of $R$ and was never less than one-twelfth of $R$ in $C R$ and $V$ leads, with rare exceptions in V7.

The $T$ wave was most positive in CR leads, and was upright in the adults examined, but it is frequently inverted in CR1 in children. In V1 it was often inverted in adults, but a right pattern chest lead with $S$ greater than $R$ was then found in V2. In V2 to V6 the $T$ wave was upright. In V7 the $T$ wave was occasionally flat or slightly inverted. A flat or inverted $T$ wave was found in any CF chest lead except CF4, and especially in CF1, CF2, and CF7.

A comparison of $\mathrm{CR}, \mathrm{V}$, and $\mathrm{CF}$ leads in health shows that $\mathrm{CF}$ is too variable to be recommended for routine use, while neither $\mathrm{CR}$ nor $\mathrm{V}$ leads have much practical advantage over each other provided that the normal pattern and variations of each are known.

I am grateful to Dr. William Evans, Physician to the Cardiac Department, and to Sir John Parkinson for much helpful advice, and to Professor Bradford Hill for help with the statistics.

\section{REFERENCES}

American Heart Association (1938). Recommendations on Standardisation of Precordial Leads, Amer. Heart J., 15, 235 
Ashman, R. (1942). Amer. Heart J., 23, 522.

- and Hull, E. (1937). Essentials of Electrocardiography, First ed., New York.

Barnes, A. R. (1940). Electrocardiographic Patterns: Their Diagnostic and Clinical Significance, Baltimore.

British Cardiac Society (1949). Recommendations on Multiple Unipolar Leads, Brit. Heart J., $11,103$.

Burger, R. (1939). Cardiologia, 3, 56.

Chamberlain, E. N., and Hay, J. D. (1939). Brit. Heart J., 1, 105.

Deeds, D., and Barnes, A. R. (1940). Amer. Heart J., 20, 261.

Dolgin, M., Grau, S., and Katz, L. N. (1949). Ibid., 37, 343.

Eckey, P., and Fröhlich, R. (1938). Arch. f. Kreislaufforsch, 2, 349.

Evans, W., and Hunter, A. (1943). Brit. Heart J., 5, 73.

Goldberger, E. (1947). Unipolar Lead Electrocardiography, First ed., New York

Graybiel, A., McFarland, R. A., Gates, D. C., and Webster, F. A. (1944). Amer. Heart J., $27,524$.

Grewin, K. E. (1948). Some Supplementary Leads in Clinical Electrocardiography, Stockholm.

Groedel, F. M. (1933). Verhandl. d. deutsch. Gesellsch. f. Kreislaufforsch, pp. 127, Steinkopff, Dresden.

(1939). Cardiologia, 3, 23 and 36.

and Borchardt, P. R. (1948). Direct Electrocardiography of the Human Heart, Brooklyn Medical Press Inc.

Hall, G. E., Stewart, C. B., and Manning, G. W. (1942). Canad. M.A.J., 46, 226.

Hecht, H. H. (1942). Amer. Heart J., 24, 529.

Hoskin, J., and Jonescu, P. (1940). Brit. Heart J., $2,33$.

Hull, E., Tucker, H. de N., and Weilbaecher, J. O. (1948). Amer. Heart J., 36, 135.

Jensen, J., Smith, M., and Cartwright, E. D. (1932). Ibid., 7, 718.

Katz, L. N. (1946). Electrocardiography, Second ed., Chicago.

, Dolgin, M., and Langendorf, R. (1948). Medical Clin. of N. America, 32, 197.

Kossman, C. E., and Johnston, F. D. (1935). Amer. Heart J., 10, 925.

Larsen, K., and Skúlason, T. (1941). Amer. Heart J., 22, 625 and 645.

Lewis, T., and Gilder, M. D. (1912). Phil. Tr. Roy. Soc., London, 202 B, 351.

Master, A. M., Dack, S., and Jaffe, H. L. (1937). Amer. J. Dis. Children, 35, 1000.

Myers, G. B., Klein, H. A., Stofer, B. E., and Hiratzka, T. (1947). Amer. Heart J., 34, 785.

Pardee, H. E. (1941). Clinical Aspects of the Electrocardiogram, Including the Cardiac Arrhythmias, Fourth ed., New York.

Shanno, R. L. (1940). Amer. Heart J., 19, 713.

Shipley, R. A., and Hallaran, W. R. (1936). Ibid., 11, 325.

Sodeman, W. A. (1937). Ibid., 14, 367.

Sorsky, E., and Wood, P. (1937). Ibid., 13, 183.

Stewart, C. B., and Manning, G. W. (1944). Ibid., 27, 502.

Suarez, R. M., and Suarez, R. M., Jun. (1946). Ibid., 32, 480.

Wallace, L., and Grossman, N. (1946). Brit. Heart J., 8, 83.

White, P. (1944). Heart Disease, Third ed., New York.

Wilson, F. N. (1937). Trans. Assn. Life Ins. Med. Directors Amer., 24, 96. , Johnston, F. D., Macleod, A. G., and Barker, P. S. (1934). Amer. Heart J., 9, 447. , Josenbaum, F., and Johnston, F. D. (1947). Advances Int. Med., 2, 1.

Wolferth, C. C., and Wood, F. C. (1940). Amer. Heart J., 20, 12.

Wood, P., and Selzer, A. (1939). Brit. Heart J., 1, 49. 